\title{
WHY DO COUNTRIES MATTER SO MUCH FOR CORPORATE GOVERNANCE?
}

\author{
Craig Doidge \\ G. Andrew Karolyi \\ René M. Stulz \\ Working Paper 10726
}


NBER WORKING PAPER SERIES

WHY DO COUNTRIES MATTER SO MUCH FOR CORPORATE GOVERNANCE?

\author{
Craig Doidge \\ G. Andrew Karolyi \\ René M. Stulz \\ Working Paper 10726 \\ http://www.nber.org/papers/w10726
}

\author{
NATIONAL BUREAU OF ECONOMIC RESEARCH \\ 1050 Massachusetts Avenue \\ Cambridge, MA 02138 \\ August 2004
}

René Stulz is grateful for the hospitality of the Kellogg Graduate School of Management at Northwestern University and the George G. Stigler Center for the Study of the Economy and State at the University of Chicago. Andrew Karolyi is grateful to the Dice Center for Research in Financial Economics for financial support. We thank Ian Byrne for providing the S\&P Transparency and Disclosure ratings. We are grateful to participants at the American Economic Association meetings, the NBER Summer Institute, and at seminars at Delaware, London Business School, Ohio State, Northwestern, University of British Columbia, Virginia, Wilfred Laurier, and Yale, and to Lucian Bebchuk, Bernard Black, Kent Daniel, Olivier Jeanne, Kose John, Simon Johnson, Han Kim, Mitch Petersen, Florencio Lopez-de-Silanes, and Bernard Yeung for useful comments. Rodolfo Martell and Carrie Pan provided excellent research assistance. The views expressed herein are those of the author(s) and not necessarily those of the National Bureau of Economic Research.

C2004 by Craig Doidge, G. Andrew Karolyi, and René M. Stulz. All rights reserved. Short sections of text, not to exceed two paragraphs, may be quoted without explicit permission provided that full credit, including (C) notice, is given to the source. 
Why Do Countries Matter So Much for Corporate Governance?

Craig Doidge, G. Andrew Karolyi, and René M. Stulz

NBER Working Paper No. 10726

August 2004

JEL No. G15

\begin{abstract}
This paper develops and tests a model of how country characteristics, such as legal protections for minority investors, and the level of economic and financial development, influence firms' costs and benefits in implementing measures to improve their own governance and transparency. The model focuses on an entrepreneur who needs to raise funds to finance the firm's investment opportunities and who decides whether or not to invest in better firm-level governance mechanisms to reduce agency costs. We show that, for a given level of country investor protection, the incentives to adopt better governance mechanisms at the firm level increase with a country's financial and economic development. When economic and financial development is poor, the incentives to improve firmlevel governance are low because outside finance is expensive and the adoption of better governance mechanisms is expensive. Using firm-level data on international corporate governance and transparency ratings for a large sample of firms from around the world, we find evidence consistent with this prediction. Specifically, we show that (1) almost all of the variation in governance ratings across firms in less developed countries is attributable to country characteristics rather than firm characteristics typically used to explain governance choices, (2) firm characteristics explain more of the variation in governance ratings in more developed countries, and (3) access to global capital markets sharpens firm incentives for better governance, but decreases the importance of homecountry legal protections of minority investors.
\end{abstract}

René M. Stulz

Fisher College of Business

Ohio State University

806A Fisher Hall

2100 Neil Avenue

Columbus, OH 43210-1144

and NBER

stulz_1@cob.osu.edu

Craig Doidge

University of Toronto

Andrew Karolyi

The Ohio State University 


\section{Introduction}

Corporate governance deals with the mechanisms that ensure that investors in corporations get a return on their investments (Shleifer and Vishny, 1997). Corporate governance varies widely across countries and across firms. Better governance enables firms to access capital markets on better terms, which is valuable for firms intending to raise funds. We would, therefore, expect firms that plan to access capital markets - especially those with valuable growth opportunities that cannot be financed internally - to adopt mechanisms that commit them to better governance.

With the availability of data on corporate governance and disclosure practices of individual companies around the world, provided first by the Center for International Financial Analysis and Research (CIFAR) and, more recently, by Credit Lyonnais Securities Asia (CLSA) and Standard and Poor's (S\&P) among others, several studies have investigated whether governance and transparency scores are related to firm characteristics, such as investment opportunities, external financing needs, asset size, or ownership structure, and to the efficiency of the legal regime in protecting minority shareholder interests (Durnev and Kim, 2004; Francis, Khurana, and Pereira, 2003; Klapper and Love, 2003; Krishnamurty, Sevic, and Sevic, 2003). In general, they find supporting evidence that the quality of governance practices is positively related to growth opportunities, the concentration of ownership, the need for external financing, and the protection of investor rights. However, until now, the importance of other country characteristics, such as the financial and economic development of the country in which a company is domiciled, and how that importance is affected by financial globalization, has not been investigated. This is surprising since a number of studies show that other country characteristics besides measures of investor protection have a significant impact on country-level measures of 
governance. ${ }^{1}$ In this paper, we find that firm characteristics, such as investment opportunities, asset size, ownership, and cash holdings, explain almost none of the variation in CLSA scores. Though firm-specific variables are more successful in explaining variation in S\&P scores, their explanatory power is dwarfed by the explanatory power of country characteristics.

Why then do countries matter so much for corporate governance? Countries matter because they influence the costs that firms incur to bond themselves to good governance and the benefits they receive from doing so. ${ }^{2}$ Better governance reduces a firm's cost of funds only to the extent that investors expect the firm to be governed well after the funds have been raised. It is, therefore, important for the firm to find ways to commit itself credibly to higher quality governance. However, mechanisms to do so may be unavailable or prohibitively expensive in countries with poor investor protection and poor economic development. For instance, credible external verification of a firm's income disclosures may not be available because insufficient economic development means that the necessary infrastructure for such verification is not available (see Ball, 2001; Black, 2001). Consequently, a firm can have potentially valuable growth opportunities, yet it takes no steps to have good governance because the tools required are too expensive or not even available in its country. Perhaps the most important benefit to a firm from having good governance is that it facilitates access to capital markets. But, this benefit is worthless if a firm is located in a country with poor financial development. Because of this poor development, the firm finds it expensive to raise funds, so that it chooses to raise a smaller amount of funds and, hence, benefits less from better governance. As a result, firms with good

\footnotetext{
${ }^{1}$ Bushman and Smith (2003) show that political characteristics are important for some types of disclosure. Dyck and Zingales (2003) show that a high level of diffusion of the press is negatively related to benefits of control. Finally, Stulz and Williamson (2003) and Hope (2003) find that proxies for cultural heritage and religion are related to disclosure.

${ }^{2}$ Our focus is on why firms in different countries have different governance quality when measured by governance indices rather than on why governance systems differ across countries. We take the governance system as exogenously given. It affect firms' corporate governance decisions. There is a large literature that contrasts governance systems across countries (see Allen and Gale, 2000). Some of that literature has focused on development as a determinant of the financial system (see, for instance, John and Kedia (2003, 2004), who show theoretically that financial development and the quality of monitoring technologies of a country affect the choice of governance mechanisms).
} 
growth opportunities may have poor governance because they are in a country where financial development and investor protection are poor. In other words, it is not worth it for the firm to take steps to bond itself to better governance.

If a country is poorly developed and protects investors poorly, it will be difficult for firms to find ways to commit to good governance and the rights of minority shareholders will be mostly determined by the characteristics of the country. Therefore, we expect country characteristics to play an overwhelming role as a determinant of governance in poorly developed countries. At the same time, we would expect that financial globalization should reduce the importance of the country determinants of governance and increase firm-level incentives for good governance in two ways. First, firms that have access to foreign capital markets and financial institutions are less dependent on the development of their country. As a result, firms from poorly developed countries find it easier to obtain capital and, therefore, have greater incentives to adopt good governance. Second, financial globalization enables firms to "borrow" the investor protection of countries where protection is high. For instance, firms can list their shares for trading in the U.S. by initiating an American Depositary Receipt (ADR) program. A number of researchers have argued that this action subjects or "bonds" the firms to U.S. securities laws (see Coffee, 1999, 2002; Doidge, Karolyi, and Stulz, 2004; Doidge, 2004; Reese and Weisbach, 2002; and Stulz, 1999). Though there are limits to the extent to which securities laws can be enforced on foreign firms (see Black, 2001; Licht, 2003; Siegel, 2004), there may well be no substitute mechanisms for firms from some countries to credibly bond themselves to good governance (see Ball, 2001, and Perino, 2003).

If it were costless for firms to adopt good governance mechanisms, regardless of the standards in the home country, then all firms would do so when they access capital markets for the first time (unless, of course, the firm's owners value control and discretion for non-pecuniary reasons). Hence, even though countries would protect investor rights differently, there would be no differences across countries in the degree to which investors are expropriated by controlling 
shareholders. Therefore, differences in the costs and benefits from implementing good governance mechanisms must be taken into account to explain why their adoption differs across countries. We construct a model where countries differ not only in how they protect investors but also in the cost of accessing capital markets and in the cost of implementing firm-level governance mechanisms. This model enables us to analyze the determinants of governance in a richer setting than previous models. If it is costlier to implement good firm-level governance and to raise funds in countries with low development, firms in such countries can find the benefit from good firm-level governance to be too small to justify the cost. Since investor protection is generally poor in countries with low development, firm-level governance may be infeasible precisely when it is needed most.

In our empirical work, we test the model's predictions using the CLSA corporate governance ratings and the S\&P transparency and disclosure ratings. These ratings measure both firm-level governance attributes adopted by firms and attributes imposed on firms through legislation and regulation. We show that almost $39 \%$ of the variance for CLSA ratings and $73 \%$ of the variance for the S\&P scores can be explained by country-level dummy variables. Adding firm-specific variables does not increase the explained variation for developing countries, so these variables explain none of the variation in governance for these countries. The same firm-specific variables explain roughly $8 \%$ of the variation in transparency scores for developed countries, so that governance is better explained by firm characteristics in these countries. Our preferred interpretation of the results is that countries matter more than firm characteristics. Of course, it is not the only possible explanation since our various specifications do not explain all of the crosssectional variation in ratings. We discuss alternate interpretations and explain why we believe that the results are consistent with our preferred interpretation.

In this paper, we use a broader sample of firms for the S\&P ratings than that used in earlier papers. As a result, we are able to estimate regressions separately for developed and developing countries, which is not possible for CLSA since almost all countries included in that sample are 
countries with GNP per capita below the median of the countries in the S\&P sample. We find that firm-specific variables are more informative about firm-level governance for firms from more developed countries, which is consistent with the key prediction of our model. In particular, firm characteristics are not significant in explaining the S\&P ratings in the countries with low development, but they are significant in countries with high development. Though splitting the sample according to economic development identifies a significant difference in how firm characteristics are correlated with governance, the same result does not obtain when we split the sample according to a measure of investor protection. For instance, the investor-protection variable used by Durnev and Kim (2004) is constructed in such a way that some countries with a low value for that variable are extremely prosperous. These are countries where the anti-director index of La Porta, Lopez-de-Silanes, Shleifer, and Vishny (1998) has an extremely low value. Interestingly, in these countries, firm characteristics do matter for governance.

We then investigate whether financial globalization enables firms to partly escape the country determinants of governance and thereby sharpens the incentives for firms with growth opportunities to have good governance. In support of our hypothesis, firm characteristics are jointly significant for firms with New York Stock Exchange (NYSE) or NASDAQ traded ("Level 2 or 3") ADR programs from low development countries, but they are not for purely local firms. Further, country-level investor protection is not a significant determinant of corporate governance for global firms in developed countries. Less supportive of our hypothesis is the result that adding firm characteristics to a regression that controls for country effects through dummy variables does not increase the adjusted R-squared differently for global firms than for non-global firms.

There is a related but distinct literature on the impact of globalization on governance. We distinguish between investor protection from the state and investor protection chosen by the firm to improve on the investor protection granted by the state, which we call "firm-level governance." In this paper, we focus on firm-level governance. The literature demonstrates that globalization has an impact on the investor protection granted by the state. For instance, as shown by 
Smarzynska and Wei (2000) and Bonaglia, de Macedo, and Bussolo (2001), countries that are more open have less corruption, so that governance and openness are related.

The paper proceeds as follows. In Section 2, we examine the choice of firm-level governance mechanisms in a model in which the cost of implementing these mechanisms and the cost of access to capital markets depend on the country in which a firm is located. In Section 3, we present our sample of firms and governance ratings. We demonstrate the paramount importance of country-specific factors and the limited importance of firm-specific factors as explanatory variables for the corporate governance ratings in Section 4. We also show that firm-specific factors are more important in more developed countries. In Section 5, we provide evidence that globalization makes the governance of firms less dependent on country-specific characteristics and more dependent on firm-specific characteristics. We conclude in Section 6.

\section{A model of choice of governance attributes by firms and financial globalization}

La Porta, Lopez-de-Silanes, and Shleifer (1999) show that most firms outside the U.S. are controlled by large shareholders. Large shareholders can extract private benefits from control of the corporation. A number of recent papers model the extraction of private benefits from the firm by controlling shareholders (Johnson, Boone, Breach, and Friedman, 2000; Lombardo and Pagano, 2001; La Porta, Lopez-de-Silanes, Shleifer, and Vishny, 2002; Durnev and Kim, 2004; Shleifer and Wolfenzon, 2002; and Doidge, Karolyi, and Stulz, 2004). These models assume either that the extraction of private benefits is costly to the firm, or that it is costly to the controlling shareholder. Regardless of the approach taken, they establish that controlling shareholders consume fewer private benefits in countries where the cost of extracting private benefits is higher.

The deadweight costs associated with the extraction of private benefits increase the cost of outside funds for the controlling shareholders. As a result, controlling shareholders for which access to capital markets is important have incentives to find ways to commit to expropriate 
fewer private benefits. The literature has shown that by increasing their ownership of cash flow rights, controlling shareholders make the extraction of private benefits more costly because they pay for more of these private benefits out of the shares they own. As the extraction of private benefits becomes more costly, it becomes optimal for controlling shareholders to consume fewer such benefits. Firms can also make extraction of private benefits more costly through better governance. For instance, by increasing the firm's transparency, controlling shareholders make it easier for outsiders to measure their consumption of private benefits and to take actions to reduce it. In this paper, we allow for a role for corporate governance.

We assume that there is a cost to improving governance. For instance, greater transparency could increase political pressures on the firm and lead to expropriation from the state (see Leuz and Oberholzer-Gee, 2003); having independent directors could be time-consuming for management and controlling shareholders and might reduce their discretion over the firm's investment policy. There is considerable skepticism in the literature that credible mechanisms, whereby the controlling shareholders commit to consume fewer private benefits, can even be adopted in countries with the worst protection of minority shareholders. In other words, in these countries, the cost of such mechanisms might be prohibitive. ${ }^{3}$ The reward to a controlling shareholder from committing to better governance is that he reduces the deadweight costs associated with the consumption of private benefits when he raises funds in public markets. It is generally assumed in the literature that these deadweight costs increase with the amount of funds raised. Consequently, the reward to better governance for the controlling shareholder is small if the extent to which he can access the capital markets is limited because of poor financial development and if the costs from committing to less expropriation are high.

Like Shleifer and Wolfenzon (2002), we consider the problem of an entrepreneur who has to raise funds to finance an investment opportunity. This entrepreneur has control of the firm, so that he is the controlling shareholder. We assume that he controls the firm regardless of the fraction of

\footnotetext{
${ }^{3}$ See Glaeser, Johnson, and Shleifer (2001).
} 
cash flow rights he owns. The key difference between our model and theirs is that we allow the firm to improve the investor protection that applies to its shareholders through better governance at a cost. We, therefore, focus our presentation on the implications of that difference. We consider an entrepreneur with wealth $W$. This entrepreneur has an investment opportunity available. An investment of capital $K$ will return $a K^{\alpha}$, the firm's cash flow before expropriation, where $0<\alpha<$ 1 and where $a>0$, after which the firm will pay a liquidating dividend. The diminishing-returnsto-scale production function is required to insure that the model has a solution when investor protection is such that it is optimal for the entrepreneur to expropriate nothing. The entrepreneur has to decide the scale of the project. If $K>W$, the entrepreneur must raise external funds.

The entrepreneur extracts private benefits after having raised funds and after the cash flow is realized. Consequently, when the entrepreneur raises funds, investors form expectations about the proportion of the firm's cash flows that he will expropriate, $f$. In this model, the entrepreneur pays a cost for expropriating shareholders on personal account; in other words, the cost is not subtracted from the firm's cash flows. The cost could represent the expected value of the punishment imposed on the controlling shareholder if he is caught expropriating minority shareholders, as in Shleifer and Wolfenzon (2002), or it could correspond to expenses that the entrepreneur incurs for setting up mechanisms through which to extract private benefits. It is assumed to be a convex function of $f, b f^{2}$, where $b$ can be a positive constant or a function, and it increases linearly with the firm's investor protection and with the firm's cash flows. This cost is given by:

$$
0.5 b f^{2} a K^{\alpha}(p+q)
$$

The cost of extracting private benefits increases with both firm-level governance and with the investor protection granted by the state. The country's investor protection is equal to $p$, where a higher value of $p$ means greater investor protection. The investor protection that applies to 
investors in the firm is equal to $p+q$, where $q$ is the investor protection under the control of the firm.

It seems reasonable to assume that the cost of increasing investor protection at the firm-level is not sensitive to firm size but increases with the amount of protection acquired. We assume that the marginal cost of firm-level governance is increasing in the quality of firm-level governance, so that we choose the functional form for the cost of firm-level governance to be $m q^{2}$, where $m$ is a positive constant. To take into account differences in financial development across countries, we assume that it costs $n(K-W)$ to raise $K-W$, where $n$ corresponds to a proportional cost of raising capital. An improvement in financial development corresponds to a decrease in $n$, where $n$ is a constant between 0 and 1 . Though existing models assume that $q=0$, Shleifer and Wolfenzon (2002) have a differential cost of funds between a closed economy and an open economy. ${ }^{4}$ In our model, the payments $n(K-W)$ and $m q^{2}$ reduce the wealth of the entrepreneur dollar-for-dollar whether these amounts are paid by him out of his own pocket or through the firm. It simplifies the analysis, but does not change anything of substance, if we assume that $n(K-W)$ and $m q^{2}$ are paid by the entrepreneur out of the liquidating dividend paid to him by the firm. Further, we assume until stated otherwise that $b$ is a constant.

The model has no risk, so that shares have to return the risk-free rate. We assume an interest rate of zero for simplicity and minority shareholders have unlimited opportunities to earn that rate of interest on other investments. Therefore, the minority shareholders acquire a fraction $(1-k)$ of cash flow rights only if their expected dividend, equal to $(1-k)(1-f) a K^{\alpha}$, is at least equal to their initial investment of $K-W$ (this is the minority shareholders' participation constraint). Since the entrepreneur will not give money away to the minority shareholders, it must be that the participation constraint of minority shareholders is binding:

$$
(1-k)(1-f) a K^{\alpha}=K-W
$$

\footnotetext{
${ }^{4}$ The exception is Doidge, Karolyi, and Stulz (2004), where firms can choose to have an ADR program which increases investor protection. There is no implementation cost to them, so $m=0$. However, the firm does not have that choice when it is set up.
} 
In this model, the entrepreneur wants to maximize the total cash flows of the firm net of the cost of extracting private benefits and of the dividend to be paid to minority shareholders:

$$
S=a K^{\alpha}-n(K-W)-m q^{2}-0.5 b f^{2} a K^{\alpha}(p+q)-(K-W)
$$

Equation (2) assumes that the participation constraint of minority shareholders is binding since that is the case we focus on. The entrepreneur maximizes (2) by choosing three variables: $K, q$, and $f$. In maximizing (2), the entrepreneur has to satisfy two constraints. First, he will only invest if $S$ is positive (the entrepreneur's participation constraint). Second, since $f$ is chosen after funds have been raised from shareholders, it has to be consistent with maximization of the entrepreneur's welfare at the time that it is chosen (the entrepreneur's incentive compatibility constraint).

In a world of perfect markets, there are no transaction and contracting costs, so $n=m=0$. In such a world, the entrepreneur would choose contracts that constrain him to select $f=0$. If it is costless for the firm to choose mechanisms that constrain the entrepreneur from expropriating minority shareholders, the entrepreneur has nothing to gain by not using these mechanisms since, ultimately, only the entrepreneur pays the deadweight costs of expropriation. If the cost of committing to a lower level of expropriation is convex and increasing in the level of commitment, as it is in our model, it will never be optimal for the entrepreneur to commit to no expropriation.

After the entrepreneur has chosen $q$ and $K$, shares are sold to outside investors for an amount equal to $K-W$. The entrepreneur then owns a fraction $k$ of cash flow rights, given by $1-(K-$ $W) /(1-f) a K^{\alpha}$, where the denominator of the second term is the firm's cash flow after expropriation, which depends on $f$. After raising funds, the entrepreneur chooses how much to expropriate by maximizing the following expression with respect to $f$ and subject to the constraint that $f$ has to be nonnegative and cannot exceed one:

$$
k(1-f) a K^{\alpha}-0.5 b f^{2} a K^{\alpha}(p+q)+f a K^{\alpha}
$$


The first term of the expression corresponds to the dividends received by the entrepreneur. The second term is the entrepreneur's cost of extraction of private benefits. Finally, the third term represents the private benefits extracted by the entrepreneur. The solution for $f$ when the participation constraint of minority shareholders is binding is:

$$
f=\frac{1-k}{b(p+q)}
$$

For given $k$, the fraction of cash flow expropriated falls as the level of investor protection provided by the state, $p$, increases, as in earlier models. In contrast to earlier models, the entrepreneur gets to choose the level of investor protection provided by the firm, $q$, and he extracts private benefits at a lower rate when $q$ is higher. Further, $f$ and $k$ are negatively related, so that an entrepreneur with a larger stake in the firm expropriates less.

Using the participation constraint of minority shareholders, equation (4) can be written as:

$$
f=\left[\frac{K-W}{(1-f) a K^{\alpha}}\right] \frac{1}{b(p+q)}
$$

Rewriting this equation, we get a quadratic equation in $f$. The solution for $f$ has to be such that $f=0$ if it is infinitely costly to expropriate shareholders. With this requirement, there is only one possible solution for $f$ :

$$
\begin{aligned}
& f=\frac{1}{2}-\frac{1}{2}\left[1-4\left(\frac{K-W}{a K^{\alpha}}\right) \frac{1}{b(p+q)}\right]^{0.5} \text { if } 4\left(\frac{K-W}{a K^{\alpha}}\right) \frac{1}{b(p+q)}<1 \\
& f=0 \text { otherwise }
\end{aligned}
$$

When the entrepreneur chooses $q$ and $K$, he also picks $f$, so that $f$ can be written as $f(K, q)$. For a given level of $K, f$ falls with $q$ and with the productivity of physical capital.

When investors invest in the firm, they want to receive back their investment since the interest rate is zero. The investment opportunity must be good enough given $f$ and the level of investor protection sufficiently high to guarantee this outcome. This means that, as in Shleifer and Wolfenzon (2002), there will be investment opportunities for which the entrepreneur will not be 
able to raise funds. If $m$ is low, the firm can improve cheaply on its country's investor protection, so that some firms, that would not go public if they had to rely on the country's investor protection alone, will choose to do so after spending to improve the firm's investor protection through better governance. In our model, the cost to a firm of improving its governance does not depend on its size. Consequently, firms that raise a small amount of outside equity - namely, those with poor growth opportunities - will not gain from improving their governance because the cost of doing so will be amortized over fewer dollars raised. We therefore expect larger firms to have better governance; further, firms have better governance when $m$ is low and when they have good investment opportunities. A high $n$ reduces the incentives of firms to improve on corporate governance because it reduces the amount of funds raised. If $m$ is high enough, firms do not adopt firm-level governance mechanisms that improve on the investor protection granted by the state. In contrast, if $m$ is zero, then all firms have the same level of investor protection and there is no expropriation. Except for Doidge, Karolyi, and Stulz (2004), the literature has effectively assumed that $m$ is infinite.

Substituting (6) into (1) and using the minority shareholders' participation constraint, the controlling shareholder maximizes:

$$
S=a K^{\alpha}-n(K-W)-m q^{2}-0.5 b f(K, q)^{2} a K^{\alpha}(p+q)-(K-W)
$$

The nonlinearity of this expression in $K$ and $q$ makes it impossible to obtain closed-form solutions for $K$ and $q$ when $b$ is fixed. However, our analysis leads to the following result:

Proposition 1. If $m=0$, all firms that raise external funds choose a value of $q$ high enough so that $f=0$, and the protection of investors by the state is not relevant. As $m$ becomes large, $q$ becomes very small, and the protection of investors depends almost exclusively on the protection granted by the state, $p$. As $p$ becomes large and $m>0, q$ becomes very small because firm-level governance mechanisms become redundant but 
are costly. Finally, for $n$ large enough, $q=0$ since the firm does not expect to raise external capital.

The important point of this proposition is that a firm's choice of governance mechanisms depends critically on the cost of implementing these mechanisms and on the cost of raising funds. These costs are determined partly by a country's investor protection but also by the country's economic and financial development. It, therefore, necessarily follows that the choice of governance mechanisms depends on country characteristics other than investor protection. If investor protection is high enough, no expropriation takes place and the adoption of firm-level governance mechanisms is not optimal. If development is too low, there is no point to the adoption of such mechanisms because firms cannot raise a sufficient amount of funds to make good governance pay. Proposition 1 implies the existence of a threshold level of economic development below which firms' incentives for good governance are trivially small and a threshold level of investor protection by the state such that, if a country reaches that level, there is little gain for firms to try to improve on that level of investor protection on their own account.

We can obtain additional results using the first-order conditions for $K$ and $q$. These first-order conditions are, respectively, for $K$ and $q$ :

$$
\begin{aligned}
& a \alpha K^{\alpha-1}=1+n+\left[b f(K, q) f_{K} a K^{\alpha}+0.5 b f(K, q)^{2} a \alpha K^{\alpha-1}\right](p+q) \\
& 2 m q=-b f_{q} f(K, q) a K^{\alpha}(p+q)-0.5 b f(K, q)^{2} a K^{\alpha}
\end{aligned}
$$

where $f_{K}$ is the partial derivative of $f(K, q)$ with respect to $K$ and is positive and $f_{q}$ is the partial derivative of $f$ with respect to $q$, which we already know to be negative. The left-hand side of equation (8a) is the marginal revenue from investing an additional dollar in production. The righthand side is the marginal cost of the additional dollar raised for the entrepreneur. In perfect financial markets, the cost would be $\$ 1$. With imperfect investor protection and financial markets, the additional terms on the right-hand side of the equation are positive, so that the cost of capital 
is higher than what it would be in perfect markets. As a result, the amount of capital invested is lower than that in perfect markets. In equation $(8 b)$, the left-hand side is the marginal cost of better governance, while the right-hand side is the marginal benefit.

We can use equation (8b) to study the comparative statics of $q$ treating $K$ as a parameter. In this case, $q$ increases with $K$ and $a$, but falls as $m$ and $p$ increase. The intuition for these results is as follows. As $K$ and $a$ increase, cash flow increases. For a constant $f$, the total amount of expropriation increases and expropriation becomes more costly for the entrepreneur. He partly offsets this increase in the cost of expropriation by increasing $q$. As $m$ increases, it becomes more costly for the entrepreneur to acquire better governance and he therefore acquires less of it. Finally, $p$ and $q$ are substitutes. An increase in $p$ decreases the marginal benefit from better firmlevel investor protection and the entrepreneur decreases the amount of firm-level investor protection he acquires. Equation (8b) does not depend on $n$ directly. Though we can derive comparative statics using equation (8b) in a straightforward way, we have to use a linear approximation of (8a) in $q$ and $K$ to obtain results. Using the linear approximation, equation (8a) implies that an increase in $n$ decreases $K$. It therefore follows from equations (8a) and (8b) that an increase in $n$ leads to a decrease in investor protection through its impact on $q$. With this analysis, the entrepreneur purchases more investor protection if the investment opportunity is more valuable (higher cash flow before expropriation), if the cost of purchasing investor protection is lower, if financial development is higher, and if investor protection guaranteed by the state is lower.

A closed-form solution for $S$ can be obtained for the case where $b$ is equal to $B(1-k)$, where $B$ is a constant. The literature has assumed that the cost of expropriation depends on $p$ but not on firm characteristics other than cash flow. The assumption that $b$ is equal to $B(1-k)$ implies that the overall cost of expropriation for the controlling shareholder falls linearly with his ownership stake in the firm. The assumption that the cost of expropriation falls as $k$ increases does not seem unreasonable. Suppose that the controlling shareholder owns $99.99 \%$ of the firm. Presumably, if 
he has some money and he is caught expropriating, he can always buy out the shareholders who own $0.01 \%$. In contrast, if the controlling shareholder owns $40 \%$ of the firm and gets caught, many more individuals will be affected and pressure on politicians to punish the controlling shareholder is likely to be much higher. So, it is reasonable to think that the political system is likely to punish more severely the controlling shareholder who owns $40 \%$ of the shares than the one who owns $99.99 \%$. A controlling shareholder who owns $40 \%$ of the shares and expropriates $10 \%$ of the cash flow of the company is also more likely to get caught than one who owns $99.99 \%$ and who expropriates the same fraction of the cash flows because the shareholders who get expropriated lose a much larger dollar amount in the former case than in the latter.

With this assumption, we can replace $b$ in equation (3) with $B(1-k)$, so that $f$ now equals $1 / B(p+q)$ and no longer depends on $k$. The value of the firm is $(1-f)$ times the firm's cash flow before expropriation:

$$
V=\left[\frac{B(p+q)-1}{B(p+q)}\right] a K^{\alpha}
$$

It then follows that $k$ is equal to:

$$
k=\frac{(B(p+q)-1) a K^{\alpha}-B(p+q)(K-W)}{(B(p+q)-1) a K^{\alpha}}
$$

Replacing $f$ by $1 / B(p+q)$ and $b$ by $B(1-k)$ in equation (7), where $k$ is defined by equation (10), we obtain a new expression for $S$ :

$$
S=a K^{\alpha}-n(K-W)-m q^{2}+(K-W)\left(\frac{1-2 B(p+q)}{2(B(p+q)-1)}\right)
$$

The entrepreneur maximizes $S$ by choosing $q$ and $K$. In this case, if the entrepreneur raises funds, he chooses $K$ to be given by: 


$$
K=\left[\frac{\alpha a(2 B(p+q)-2)}{(2 B(p+q)-2) n+2 B(p+q)-1}\right]^{\frac{1}{1-\alpha}}
$$

There are four important comparative statics for $K$ in equation (12):

1) An increase in $a$ increases $K$. An increase in $a$ means that the investment opportunity of the entrepreneur is better, so that the marginal product of capital increases and he invests more.

2) An increase in $n$ decreases $K$. If $n$ is high, as in poorly developed financial markets, it is more expensive to raise funds, so that the entrepreneur raises a smaller amount of funds and invests less.

3) An increase in investor protection from the firm, $q$, is associated with an increase in $K$ because expropriation falls.

4) An increase in investor protection from the state, $p$, is associated with an increase in $K$ since the entrepreneur expropriates less.

In equation (12), $K$ depends on $q$. We can substitute equation (12) in the first-order condition for $q$. This yields a polynomial in $q$. The comparative statics are straightforward to evaluate when $S$ is a concave function of $q$, which has to be the case for an interior solution for $q$ to exist. Consequently, we obtain the following result:

Proposition 2. Provided that there is an interior solution for $q$ and the entrepreneur raises outside equity, a lower $q$ is chosen, or in other words, the firm adopts fewer restraints on the expropriation of investors, as:

P1. The cost of adopting these restraints, $m$, increases;

$\mathrm{P} 2$. The protection of investor rights through the state, $p$, increases; 
P3. The cost of accessing capital markets, $n$, increases;

P4. The investment opportunities of the firm, $a$, worsen.

Note that Proposition 2 has the same results as those obtained earlier when evaluating the first-order conditions (8a) and (8b) and using a linear approximation in the comparative static analysis. The intuition for the results is the same as the one given then.

If we view $\Omega=p+q$ as the measure of investor protection that takes into account the protection granted by the state, $p$, and the additional protection granted by the firm, $q, \Omega$ increases with $p$, falls with $m$, increases with $a$, and falls with $n$. The impact of an increase in $p$ on $\Omega$ is less if $m$ is low because $p$ and $q$ are closer substitutes.

Our model provides a richer and, we believe, more realistic analysis of the determinants of corporate governance at the firm level. With this model, bad institutions and low levels of economic and financial development limit the incentives of firms to improve corporate governance on their own. Firms sell shares to the public in countries that differ strongly in the degree of protection of investor rights and in the level of economic development. Though existing models focus on the protection of investor rights, the extent to which firms improve corporate governance depends critically on the development of capital markets. To see this, suppose that capital markets differ across countries in the extent to which they can absorb equity issues. In other words, firms in a country with poorly developed markets are constrained in issuing equity while firms in countries with well-developed markets are not. In our model, this is equivalent to making $n$ a step function, so that, beyond a given level of capital raising activity, $n$ is large enough to prevent more capital raising activity. Among constrained firms, the benefit of improving governance is limited since doing so does not enable them to raise more funds. Suppose now, however, that a constrained firm gains access to global markets. In this case, it 
becomes more valuable for the firm to improve governance because it can raise more funds as a result of doing so.

We have considered a firm at inception. We assumed that the exogenous variables are given and are non-stochastic. Since the solutions for $q$ and $K$ depend non-linearly on the exogenous variables, making these variables stochastic would complicate the problem considerably. Suppose, however, that a firm has chosen $q$ and $K$, has sold equity, and unexpectedly faces a change in one of the exogenous variables. In this case, any improvement in firm-level governance has an additional cost, which is that it creates a wealth transfer from the controlling shareholder to the other investors in the firm. For constant $\alpha$, the firm will not move to the level of firm-level governance it would have chosen at its inception with that level of the exogenous variable. Therefore, if $a$ unexpectedly increases, so that it would be optimal to expand production, improve firm-level governance, and raise more funds, the firm will do some of that if $m$ and $n$ are not too high. But the extent to which it changes firm-level governance will be limited by the redistribution cost. More generally, we have the following result:

Proposition 3. Provided that $m$ and $n$ are not too large, firm-level governance improves following an unexpected decrease in $p$, an unexpected decrease in $n$, an unexpected decrease in $m$, and an unexpected increase in $a$ keeping $\alpha$ constant.

With this result, we expect globalization to reduce $n$ by opening up new capital markets for firms and creating more competition in the financial intermediation industry. It should also reduce $m$ by enabling firms to access new contracting technologies and by expanding the range of financial services accessible to firms. Hence, from this perspective, we would expect financial globalization to lead to an increase in $q$ for firms that would benefit from financial globalization. 


\section{Data}

We want to explain firm-level choices of corporate governance. For that purpose, we use the Credit Lyonnais Securities Asia (CLSA) and the Standard and Poor's (S\&P) corporate governance and transparency ratings. The CLSA ratings cover emerging countries and newlyemerged countries. The S\&P ratings cover both developed and emerging economies. Both ratings evaluate many objective and some subjective indicators of firm governance practices, including categories related to managerial incentives, timely and accurate disclosures, board independence, board accountability, enforcement and management accountability, minority shareholder protection and social responsibility. While the S\&P ratings leave relatively little room for subjectivity compared to the CLSA rating, subjectivity is also limited in the CLSA rating.

Our sample construction begins with the list of firms included in the two ratings systems. The CLSA survey was conducted in 2001 and it rates the corporate governance practices of 495 firms from 25 countries. ${ }^{5}$ This survey has been used in a number of recent papers (for instance, Chen, Chen, and Wei, 2003; Palepu, Khanna, and Kogan, 2002; Durnev and Kim, 2004; Klapper and Love, 2003; and Krishnamurty, Sevic, and Sevic, 2003). The main criterion for including firms in the CLSA survey is firm size and investor interest. The CLSA corporate governance rating is based on a questionnaire given to financial analysts who responded with "Yes" or "No" answers to 57 questions related to seven categories: management discipline, transparency, independence, accountability, responsibility, fairness, and social responsibility. A composite governance rating is computed by giving an equal weight of $15 \%$ to the first six categories and a weight of $10 \%$ to social responsibility. Percentage scores on the composite governance ratings range from 13.9 to 93.5. We do not include financial firms both because they are often subject to regulations and laws that other firms are not and because financial ratios have a different meaning for them. After removing financial firms, there are 376 firms in the CLSA sample.

\footnotetext{
${ }^{5}$ See Amar Gill, 2001, Credit Lyonnais Securities Asia, Corporate Governance in Emerging Markets: Saints and Sinners, Who's Got Religion? Khanna, Kogan, and Palepu (2002) provide an evaluation of the quality of the CLSA data set.
} 
In addition to the CLSA survey, we use transparency and disclosure ratings provided by Standard and Poor's. ${ }^{6}$ The Standard and Poor's ratings have also been used in recent research (Khanna, Palepu, and Srinivasan, 2003; Durnev and Kim, 2004). The sample provided to us by Standard and Poor's in April 2003 covers 901 firms from 40 countries. S\&P compiles the ratings by examining firms' annual reports and standard regulatory filings for disclosure of 98 items, divided into three sections: financial transparency and information disclosure (35 items), board and management structure and process (35 items), and ownership structure and investor relations (28 items). S\&P uses a binary scoring system in which one point is awarded if a particular item is disclosed. The scores are added and converted to a percentage score, with scores ranging from 15.22 to 88.78. After removing financial firms, there are 711 firms from 39 countries.

Table 1 describes the sample constructed from the two surveys. It is immediately apparent that S\&P covers many more countries than CLSA. Further, the number of firms covered within a country differs sharply across countries. In some countries, like Argentina for CLSA and New Zealand for S\&P, only one firm is covered. We, therefore, check if all of our results reported below differ if we include all countries covered by a survey or if we include only countries for which at least five firms are rated. We find that including only countries for which five firms are rated makes little difference. It is also clear that there is substantial variation in ratings within countries as well as across countries. For CLSA, the lowest-rated country is Indonesia with an average score of 37.06 , with scores ranging from 13.90 to 64.90 , and the highest-rated country is South Africa with an average score of 68.38 , with scores ranging from 45.00 to 82.60 . For S\&P, the lowest-rated country is Colombia (one firm with a score of 19.15) and the highest-rated is Finland (average score of 75.70). We also give information in the table on the number of firms in each sample that have a Level 2 or 3 ADR program. Firms with Level 2 or 3 ADRs are firms listed either on the NYSE/AMEX or on NASDAQ. Level 3 ADR firms have also raised equity in

\footnotetext{
${ }^{6}$ See Patel, Balic, and Bwakira (2002) for a description of the S\&P measure. Bushee (2003) provides an extensive discussion of the properties of the S\&P ratings.
} 
the U.S. ${ }^{7}$ To determine if a firm is listed on a U.S. exchange, we use information obtained from the Bank of New York, Citibank, the NYSE, and NASDAQ. Listing dates are verified using Lexis-Nexis searches and by examining 20-Fs filed with the SEC and firm's annual reports.

To test our hypotheses, we require data on firm and country characteristics. Firm-level data for sales growth, total assets, ownership, cash holdings, and SIC (Standard Industrial Classification) codes are from Thomson Financial's Worldscope database. Sales growth is measured as the two-year geometric average of annual inflation-adjusted growth in sales from 1998-2000. Sales growth is winsorized at the $1^{\text {st }}$ and $99^{\text {th }}$ percentiles to reduce the impact of outliers. Total assets, for the year 2000, are measured in millions of U.S. dollars. Ownership is the data item reported as "Closely-held shares" for the year 2000. Worldscope defines closely-held shares as shares held by insiders, which include senior corporate officers and directors, and their immediate families, shares held in trusts, shares held by another corporation (except shares held in a fiduciary capacity by financial institutions), shares held by pension/benefit plans, and shares held by individuals who hold five percent or more of shares outstanding. In Japan, closely-held shares represent the holdings of the ten largest shareholders. For firms with more than one class of shares, closely-held shares for each class are added together. The ownership measure is far from perfect since it relies on information disclosed by firms and this disclosure is often voluntary and unmonitored. Cash holdings correspond to liquid assets held by firms and are normalized by total assets.

Sales growth is a widely used proxy for growth opportunities (see, for instance, La Porta, Lopez-de-Silanes, Shleifer, and Vishny, 2002). The difficulty with sales growth is that it is affected by a country's institutions and business conditions. As an alternative measure of growth opportunities that does not suffer from that problem, we also use a measure of dependence on external finance (Rajan and Zingales, 1998) defined as capital expenditures minus cash flows from operations divided by capital expenditures. This latter variable for these non-U.S. firms is

\footnotetext{
${ }^{7}$ See Table 1 of Foerster and Karolyi (1999) for more details on types of ADR listings.
} 
computed using data on capital expenditures and cash flows for firms from the same industry in the U.S. The motivation for this approach is that, assuming that growth opportunities of firms in the same industry have a significant common component across countries, the level of external financing of U.S. firms is the level that firms in other countries would have if they were not constrained by the poor development of the country in which they are located. Francis, Khurana, and Pereira (2003) use this measure to explain CIFAR disclosure scores and find that the 19911993 scores are positively related to the original Rajan and Zingales (1998) measure. We do not use the original measure because the CLSA and S\&P scores are for the early 2000s and the original Rajan and Zingales (1998) estimates are for the 1980s. We match U.S. and non-U.S. firms by industry at the three-digit SIC code level. Data for this measure is obtained for all U.S. firms included in S\&P's Compustat database from 1995-2000. For each firm, the use of external finance is summed from $1995-2000$ and it is divided by the firm's total capital expenditures from 1995 to 2000 . At the three-digit SIC code level, we take the industry median. Sample firms with the same three-digit SIC are assigned the industry median value.

Finally, we use a number of country-level variables in our analysis. The indices of antidirector rights, rule of law, and risk of expropriation are measures of shareholder rights, enforcement, and property rights obtained from La Porta, Lopez-de-Silanes, Shleifer and Vishny (LLSV, 1998). These variables are not available for China, Hungary, Poland, or Russia in the LLSV study. Values for anti-director rights and rule of law for these countries are taken from Pistor, Raiser, and Gelfer (2000). However, the index of the risk of expropriation is not available in their study. We follow Durnev and Kim (2004) and define "Legal" as the product of antidirector and rule of law. Stock market capitalization divided by GDP (Gross Domestic Product) is from Beck, Demirguc-Kunt, and Levine (2001) and Gross National Product (GNP) per capita is from the World Bank's World Development Indicators database.

The surveys create two selection biases. The first bias is related to country coverage. Lessdeveloped countries and those in which financial and legal institutions are especially poor will not 
be represented in the survey because they will not have firms in which the survey-sponsoring organizations would have any interest. In these countries, firms will not have been able to overcome country characteristics to draw interest from the survey-sponsoring organizations. This bias leads us to understate the potential importance of country characteristics.

The second bias is related to company coverage within countries. Only a subset of firms is rated in each country. To investigate this bias, we collected data on almost 15,000 non-financial firms available on Worldscope that are in countries covered by the surveys. We then estimated logit regression models to predict which firms have a CLSA rating and which firms have an S\&P rating. In the logit regressions, the dependent variable takes a value of one if a firm is in the CLSA or S\&P samples and the explanatory variables are the firm characteristics that we subsequently use to explain the ratings in our empirical work. The results are presented in the Appendix. It is interesting to note the similarities and differences in the firm coverage for the two samples. In both logit regressions, firm size is significant with a positive coefficient. However, inside ownership has a positive and significant coefficient in the CLSA rating regression and, by contrast, a negative and significant coefficient in the S\&P rating regression. Finally, the ratio of cash holdings to total assets has a positive significant coefficient in the S\&P rating regression and firm sales growth has a positive and significant coefficient in the CLSA regression. The explanatory power of these two models differs dramatically. Firm characteristics explain proportionally much less of the selection process by CLSA (pseudo $\mathrm{R}^{2}$ of $13.15 \%$ ) than of the selection process by $\mathrm{S} \& \mathrm{P}$ (pseudo $\mathrm{R}^{2}$ of $44.51 \%$ ). It is clear from this that larger firms are more likely to have a rating. Our theory shows that larger firms may have more incentives to adopt good governance. If that is the case, our study may understate the importance of firm characteristics because the firms in the CLSA and S\&P sample are more homogeneous than the population of firms. 


\section{How important are country and firm characteristics for governance ratings?}

In this section, we evaluate the importance of country and firm characteristics in explaining firm-level governance choices. We first regress the governance ratings on firm characteristics. The governance ratings combine investor protection granted by the state and investor protection chosen by firms beyond the requirements of the state. Using the notation of the model, the governance ratings are proxies for $p+q$. Our theory is about $q$. We assume that the part of the rating corresponding to investor protection granted by the state is uniform across firms, so that it does not depend on firm characteristics. If we find that the rating does depend on firm characteristics, we assume it is because these characteristics influence the firm's choice of firmlevel governance.

The analysis of Section 2 predicts that firms with a greater demand for external finance are firms that will adopt more constraining governance practices. We, therefore, add sales growth to the regression since it is a measure of investment opportunities that has been frequently used in the literature. Existing papers show that sales growth is significant in explaining the CLSA ratings in regressions that control for firm characteristics and investor protection (Durnev and Kim, 2004; Klapper and Love, 2003). In addition, we include the Rajan and Zingales measure of dependence on external finance as an alternative measure of growth opportunities.

We also use firm size as a firm characteristic. Our model assumes that the cost of good governance is a fixed cost but the benefit is amortized over all of a firm's security issues. We, therefore, expect that large firms are more likely to adopt such practices. However, it is also possible that large firms face a greater cost of transparency. This could arise because large firms may benefit more from connections to the political authorities than other firms, which may lead them to seek less transparency to hide these benefits, or because they may be more likely to be expropriated by the state (see Zimmerman, 1983).

Ownership by the controlling shareholders affects the choice of governance practices at the firm level. There is a subtle distinction, however, between the impact of ownership on the firm's 
level of expropriation of minority shareholders and on the governance practices adopted by the firm. In existing models, greater concentration of ownership leads to less expropriation because the controlling shareholder expropriates more from himself as his stake increases, so that the payoff from expropriation falls. This result holds even if the controlling shareholder does not take actions at the firm level to reduce his ability to expropriate shareholders, so that it has nothing to do with the firm or the governance mechanisms of the firm. Our model is focused on the choice of governance mechanisms by the firm. As the controlling shareholder owns more shares, we would expect him to invest less in firm-level governance mechanisms if those are costly because his incentives to expropriate are lower. This makes it difficult to make predictions about how ownership and governance scores are related. To the extent that CLSA partly measures the extent of expropriation, ownership could be positively related to the score. It seems less likely that the S\&P scores measure expropriation and more likely that they reflect the adoption of firm-specific governance mechanisms. We would, therefore, expect a negative relation between S\&P scores and ownership.

Finally, we employ a variable that computes the ratio of cash holdings to total assets. We would expect firms with more cash to be less likely to access the capital markets. Consequently, we would expect a negative relation between cash holdings and governance. However, firms that have just accessed the capital markets may also have higher cash holdings, and these firms should also have better governance ratings. Further, cash holdings may also proxy for growth opportunities, in which case we would also expect them to be positively associated with governance.

Panel a of Table 2 reports the regression estimates for the CLSA ratings. Model (1) shows the regression of governance ratings on firm characteristics. Two firm characteristics, sales growth and the cash-to-assets ratio, are significant and both with a positive coefficient. In all specifications, we report an F-statistic for a test of the joint significance of all firm and/or country variables. In Table 2, these F-statistics for firm-level variables are always significant at the 1\% 
level. The adjusted $\mathrm{R}^{2}$ from an OLS regression is $4.24 \%$. The t-statistics and F-statistics are reported from a regression that takes into account the potential clustering of the error terms within countries. ${ }^{8}$ In the next specification (2), we investigate the role of country characteristics. We use country variables used in the literature before, namely the "Legal" variable used by Durnev and Kim (2004), the log of GNP per capita, and the ratio of stock market capitalization to GDP. We see that these country variables explain much more of the variation in ratings than firm-specific characteristics. Legal and GNP per capita are extremely highly correlated, but Legal has a significant positive coefficient while the other two country characteristics are insignificant. In the next specification, we regress the ratings on both sets of country characteristics and firm-specific characteristics. The adjusted $\mathrm{R}^{2}$ increases and the F-statistics indicate that both firm and country characteristics are both jointly significant. All the variables that were significant in models (1) and (2) remain significant.

In model (4), we estimate a statistical upper-bound on the importance of country-specific characteristics by regressing the governance ratings on country dummy variables. We see that the adjusted $R^{2}$ of that regression is about two and a half times the adjusted $R^{2}$ of model (2). This indicates that variables that researchers have focused on capture only a fraction of the country characteristics that can potentially influence governance scores. Comparing model (4) to model (1), we see that the adjusted $R^{2}$ of the country dummy regression is nine times that of the regression with firm-specific variables. Consequently, the country characteristics dominate firm characteristics in explaining the variation in firm governance ratings. In model (5), we estimate (1) but with country dummies. The improvement in adjusted $R^{2}$ obtained by adding firm-specific variables to (5) is trivial. Further, sales growth is no longer significant. In other words, part of the

${ }^{8}$ A model using country random effects would also correct for within-country correlation. However, Hausman tests indicate that the assumptions of the model are not met and that the random effects estimator is not valid. Therefore, we use OLS regressions with clustered robust standard errors to account for within country correlation of the error terms - observations within a country are not treated as independent, but observations across countries are. The clustered standard errors are similar to heteroscedasticity-consistent standard errors (White, 1980) except that the weights are sums over each country (cluster). See Rogers (1993) and Williams (2000) for further details. 
success of sales growth seems to be explained by its correlation with country characteristics. The only firm-specific variable that is significant is the cash-to-assets ratio, with a coefficient of 11.51 and a t-statistic of 2.15.

We turn next to the S\&P governance ratings. The results are reported in Panel b of Table 2. It is immediately striking that firm characteristics explain much more of the variation in the S\&P ratings than they do of the variation in the CLSA ratings. Model (1) regresses the S\&P ratings on firm-specific characteristics. The adjusted $\mathrm{R}^{2}$ is $22.49 \%$, which is more than five times the adjusted $\mathrm{R}^{2}$ of the same regression for the CLSA rating. Surprisingly, sales growth is not significant but the measure of dependence on external finance is and with a positive coefficient. As in Panel a, the cash-to-assets ratio has a positive and significant coefficient. Further, firm size is also significant. In the regression with country characteristics, Legal is not significant but the $\log$ of GNP per capita is. The adjusted $\mathrm{R}^{2}$ is roughly twice the adjusted $\mathrm{R}^{2}$ for the comparable regression in Panel a. Model (3) adds the set of firm characteristics to model (2). The only significant variables in that regression are the measure of dependence on external finance and firm size. None of the country characteristics are significant, though the F-statistic associated with the joint test that they equal zero is rejected (F-statistic of 4.60). As in Panel a, country characteristics capture much less of the variation in governance ratings than country dummy variables. We find in model (4) that the $\mathrm{R}^{2}$ using country dummy variables is $73 \%$ - more than twice the $\mathrm{R}^{2}$ using country characteristics. Finally, when we combine firm characteristics with country dummies in model (5), the adjusted $\mathrm{R}^{2}$ increases by a relatively small amount. Again, only the dependence on external finance and firm size are significant.

It follows from the regressions in Table 2 that firm-specific characteristics have very little explanatory power for the CLSA ratings and only some explanatory power for the S\&P ratings. Irrespective of the rating system, country characteristics explain more of the variation in ratings than firm characteristics. The greater importance of country characteristics is most obvious when 
we use country dummy variables. The country characteristics used in the literature capture only a fraction of the variation in ratings due to country effects.

Our model predicts that firm characteristics matter more as development increases, up to a point. We next investigate whether firm characteristics explain more of the variation in the ratings for developed countries relative to less developed countries. A comparison of developed and less developed countries is more meaningful for the S\&P ratings. We therefore restrict our analysis to these ratings. Table 3 presents the results.

Panel a of Table 3 splits the sample of the countries for which S\&P ratings are available into highly developed and less developed countries. We do this by splitting the countries into countries with above-median GDP per capita, the highly developed countries, and below-median GDP per capita, the less developed countries. The results are striking. First, when we regress the ratings on firm characteristics, the adjusted $\mathrm{R}^{2}$ is $15.54 \%$ for the highly developed countries and $2.19 \%$ for the less developed countries. None of the firm characteristics are significant in explaining the ratings of the less developed countries. The F-statistic of 13.40 is significant for the highly developed countries, but not for the less developed countries (F-statistic of 0.81). In the highly developed countries, the rating increases with dependence on external finance, falls with ownership concentration, and increases with firm size as predicted by our model. Country dummies explain $51.72 \%$ of the variation in ratings for the highly developed countries and $48.12 \%$ for the less developed countries. Adding the firm characteristics to the regression with only country dummies increases the adjusted $\mathrm{R}^{2}$ from $51.72 \%$ to $59.81 \%$ for highly developed countries and decreases from $48.12 \%$ to $48.00 \%$ for the other countries. The F-statistic of the joint test of the firm-level variables is significant for the highly developed countries (F-statistic of 7.25) and insignificant for the less-developed countries (F-statistic of 1.60) This finding confirms that firm characteristics are not useful to understand governance ratings in countries with low economic development and are more useful to understand these ratings in countries with high economic development. 
As discussed in the previous section, the governance ratings measure governance mandated by the state and how a firm goes beyond the requirements of the state. While the ratings measure $p+q$, we would like to isolate $q$, the firm-level governance. In Panel $\mathrm{b}$ of Table 3, we assume that $p$ is proxied by the lowest firm score in a country. In other words, we assume that firms with higher scores achieved these scores because of firm-level governance. We then introduce a new dependent variable, which is based on a difference of scores among firms within a country and which we define as (Firm score - Country minimum)/(100 - Country minimum). Multiplied by 100 , this new dependent variable takes values from 0 to 100 like the S\&P score itself. It is useful to think of this new variable as the firm-level governance score. It will depend on country characteristics, since the benefit from improving governance at the firm level depends on country characteristics. When we regress the firm-level governance difference score on firm characteristics, we find that these characteristics explain much more of the variation of the score in developed countries than in less developed countries. However, country dummies explain more of the variation of the difference score than firm characteristics irrespective of the level of development. Finally, we also see that adding firm-level characteristics to the regression with country dummy variables increases $\mathrm{R}^{2}$ much more for more developed countries than for the other countries. The F-statistics for the significance of firm characteristics are always significant for highly developed countries (14.82 in model (1), 20.18 in model (3), and 9.63 in model (5)), but only marginally so in model (8) and not at all in models (6) and (10) for less developed countries.

In Table 4, we split the S\&P sample using the legal index in which high (low) investorprotection countries are those with Legal scores above (below) the median. The firm-specific variables are jointly significant relative to country factors and even country dummies for not only firms in high investor-protection countries but also those in low investor-protection countries. The results do not draw the same sharp distinction as with GNP per capita in Table 3. One issue is that, whereas GNP per capita works well at separating the sample of countries into two very 
distinct groups of countries, the same cannot be said for the Legal variable. GNP per capita and Legal have a correlation of 0.52 . However, Legal takes low values for countries that have a low anti-director index. For instance, Argentina and Malaysia have an above-median Legal index in contrast to the Netherlands, Germany, and Switzerland, but Argentina and Malaysia have a below-median GNP per capita, in contrast to these European countries.

In our regression analysis, we focus on an index of the legal system (Legal), a measure of economic development (GNP per capita), and a measure of financial development (Stock market cap per GDP) as the country-specific explanatory variables. One might argue that other country variables should affect firm governance. Most importantly, the extent to which property rights are enforced is important. Recent research (see Acemoglu and Johnson, 2003) shows that the respect of property rights is an important determinant of economic growth. In the model of Section 2, poor respect of property rights would make it less valuable to invest in governance since controlling shareholders who are more likely to be expropriated by the state gain less from investing in corporate governance. However, respect of property rights is strongly correlated with GNP per capita, so that our specifications might already account for the effect of this propertyrights variable. Nevertheless, we re-estimated our regressions with country characteristics with an additional variable that captures respect of property rights. This variable is the risk of expropriation index used by LLSV (1998). This index takes values from one through 10, where a value of one indicates the highest risk of expropriation. Using this variable restricts our sample size because it is not available for China or any of the former Eastern bloc countries. For the regressions in Table 2 that have both country and firm characteristics, we find that the coefficient on the expropriation index is not significant in the regression for the CLSA ratings, but it is positive and highly significant in the regression for the S\&P ratings. For the S\&P ratings, governance is inversely related to the expropriation index, so that countries with a higher risk of expropriation have worse governance as we would expect. Consequently, the risk of expropriation from the state is an important country characteristic. However, taking that 
characteristic into account changes none of our basic inferences, although it increases the proportion of the cross-sectional variation in governance ratings that can be explained by country characteristics.

We have found evidence that is supportive of our hypotheses. At the same time, however, there are important limitations to our approach. One such limitation is that we risk underestimating the role of firm characteristics by virtue of our regression analysis. We know we fully account for country characteristics whose impact is unrelated to firm characteristics through the dummy variables, yet it could be that what we do not explain is simply related to firm characteristics we do not observe. If this is the case for the S\&P ratings, this would likely not overturn our conclusions because country characteristics alone explain $73 \%$ of the variation in the ratings. Since the country dummy variables explain only $38 \%$ of the variation of the CLSA ratings, it is possible that firm characteristics we are omitting from the analysis somehow explain more of the dispersion in the ratings than country dummy variables themselves. Part of the problem here could be mechanical, however. The CLSA rating countries have much less variation in country characteristics than those for the S\&P ratings because there are simply fewer countries represented in that sample. If we had a rating for just one country after all, it would not be surprising that all of the variation in those ratings were found to be explained by firm characteristics. This is precisely why we have focused more on the S\&P ratings.

We have restricted our focus on those firm characteristics that have been used most often in the literature. We investigated whether other characteristics used would help explain the ratings better and have not had success. To address the concern about omitted firm characteristics, we collected Worldscope data on ten additional firm characteristics (profitability, turnover, and leverage measures) and incorporated them into the existing regression specifications, not worrying about multicollinearity since the focus is on overall explanatory power. By doing this, we increase the adjusted $\mathrm{R}^{2}$ of model (1) in Table 3 from $17.74 \%$ to $21.74 \%$, but the adjusted $\mathrm{R}^{2}$ of model (6) increases only from $1.74 \%$ to $2.77 \%$, so that for less-developed countries, firm 
characteristics have trivial explanatory power even when we use the largest specification possible. We estimated these regressions using three-year averages for firm characteristics, but the results were similar. Since the S\&P ratings are determined by objective criteria, it cannot be that the analysts who prepared the ratings used information about firms that was not available to investors in general.

So, what would help explain more of the variation in the ratings? Two explanations are consistent with noise being the explanation. First, it could be that there is simply random variation in governance ratings. Suppose there are governance attributes that are cheap to adopt but also have little impact. Some firms might adopt them, others not. Such attributes would be economically unimportant, but they would drive down the $\mathrm{R}^{2}$ of our regressions. Second, there could be systematic and idiosyncratic mistakes in the ratings.

Could there be more at work in these ratings than noise? The limitations of our database suggest that it ought to be so. With the rating, we do not know when a firm adopted a particular provision. It might have done so in response to a change in some firm characteristic or the market environment, but since then this change may have disappeared. Governance provisions are sticky, so that even though firm characteristics changed, the provision might have remained in effect. Unfortunately, there is nothing that we can do to deal with that issue. However, it suggests that the time-series path of firm characteristics likely matters. Further, a firm might have adopted governance provisions in response to specific attributes that we (and other researchers) have not observed.

\section{Does financial globalization reduce the importance of country characteristics?}

Our model predicts that country characteristics should be less important for firms that access the global markets. To examine this issue, we re-estimate the regressions of Table 3 that use the S\&P ratings, but now we split each subsample further into two groups, namely firms with a Level

2 or 3 ADR (which we call "global firms") and other firms ("non-global firms"). We expect from 
our theory that firm characteristics should be more relevant in explaining the S\&P rating for firms in highly developed countries and for global firms in less developed countries. We also expect that country characteristics should be less relevant for these firms. Panel a of Table 5 shows estimates for the regressions for firms in highly developed countries. For global firms, the Fstatistic for the joint test that firm characteristics are irrelevant always rejects the null (3.24 for model (3) and 8.86 for model (5)). For non-global firms, the F-statistic for firm characteristics is insignificant in the regression specification that has no other variables but firm characteristics. However, when we add country characteristics or just country dummies, firm characteristics become significant explanatory variables (F-statistic of 4.18 in model (8) and 3.10 in model (10)). Two results are not supportive of our model, however. Country characteristics are significant for global firms as well as for non-global firms and explain more of the cross-sectional variation in governance ratings for global firms; firm characteristics increase the adjusted R-squared when added to country dummy variables as much for non-global firms as they do for global firms.

In panel $b$, we turn to firms in less developed countries. The F-statistic for firm characteristics is always significant for global firms (2.53 in model (3) and 3.73 in model (5)). At the same time, however, adding firm characteristics to the country dummy variables does not improve the overall explanatory power of the regression, as the adjusted $R^{2}$ declines from 0.4352 to 0.4301 . When we consider non-global firms, the F-statistic for firm characteristics is always insignificant (1.13 in model (8) and 0.72 in model (10)). We also split the sample of CLSA firms in less developed countries into global and non-global firms and these results are presented in panel c. We have proportionally fewer "global" firms that have Level 2 or 3 ADRs in the CLSA sample. Nevertheless, we find that when controlling for the country characteristics used in the literature, firm characteristics are insignificant for non-global firms and significant for global firms. The result has to be treated with caution, though, because it does not hold when country characteristics are controlled for with dummy variables. 
Our theory also implies that home-country investor protection should be less important for global firms. The evidence supportive of this prediction is limited for the S\&P sample. For firms from highly developed countries, we find that Legal is significant for firms that are not global, but it is not for global firms. For less developed countries, Legal is negative and significant both for global firms and non-global firms for the S\&P sample. It is insignificant for global firms for the CLSA sample and positive and significant for the non-global firms in that sample.

\section{Conclusion}

In this paper, we distinguish between the investor protection granted by the state and investor protection adopted by the firm. We show that the extent to which firms choose to improve upon the investor protection granted by the state depends on the costs and benefits of doing so. In countries with weak development, it is costly to improve investor protection because the institutional infrastructure is lacking and good governance has political costs. Further, in such countries, the benefit from improving governance is weaker because capital markets lack depth. However, financial globalization reduces the importance of country characteristics, thereby increasing the incentives for good governance.

Using the CLSA corporate governance ratings and the S\&P transparency and disclosure ratings, we find that a large fraction of the variation in these ratings that can be explained is attributable to country characteristics. Firm characteristics explain more of the cross-sectional variation in corporate governance in more developed countries and country characteristics matter less for firms that have access to global markets. A possible explanation for these results is that the ratings are better at evaluating firm-level governance in more developed countries or for more global firms. This would be more surprising for the S\&P ratings than for the CLSA ratings because the CLSA ratings have more of a subjective element. It could also be that firm characteristics are measured more accurately in more developed countries. Finally, though we use firm characteristics that the literature has believed to be associated with governance, it might be 
that omitted firm characteristics or past values of firm characteristics play a more significant role in explaining the ratings. Nevertheless, we believe that the evidence presented here is consistent with the view that, while the investor protection granted by the state is an important determinant of corporate governance, so are the levels of economic and financial development as well as the openness of a country. 


\section{References}

Acemoglu, D., and S. Johnson, 2003, Unbundling Institutions, working paper, Massachusetts Institute of Technology, Cambridge, MA.

Allen, F., and D. Gale, 2000, Comparing financial systems, MIT Press, Cambridge, MA.

Ball, R., 2001, Infrastructure requirements for an economically efficient system of public financial reporting and disclosure, Brookings-Wharton Papers on Financial Services, 127-169.

Beck, T., A. Demirguc-Kunt, and R. Levine, 2001, A new database on the structure and development of the financial sector, World Bank Economic Review.

Black, B., 2001, The legal and institutional preconditions for strong securities markets, ULCA Law Review 48, 781-855.

Bonaglia, F., J.B., de Macedo, and M. Bussolo, 2001, How globalization improves governance, CEPR working paper, London.

Bushee, B., 2003, Discussion of 'Disclosure practice of foreign companies interacting with U.S. markets,' Journal of Accounting Research, forthcoming.

Bushman, R., J. Piotroski, and A. Smith, 2003, What determines corporate transparency?, working paper, University of Chicago.

Chen, K., Z. Chen, and K. Wei, 2003, Disclosure, corporate governance, and the cost of equity capital: evidence from Asia's emerging markets, working paper, Hong Kong University of Science and Technology.

Coffee, J., 1999, The future as history: the prospects for global convergence in corporate governance and its implications. Northwestern University Law Review 93, 641-708.

Coffee, J., 2002, Racing towards the top? The impact of cross-listings and stock market competition on international corporate governance. Columbia Law Review, 102, 17571831 .

Doidge, C., 2004, U.S. cross-listings and the private benefits of control: evidence from dual-class firms, Journal of Financial Economics 72, 519-553.

Doidge, C., A. Karolyi, and R. Stulz, 2004, Why are foreign firms listed in the U.S. worth more?, Journal of Financial Economics 71, 205-238.

Durnev, A., and Kim, E.H., 2004, To steal or not to steal: firm attributes, legal environment, and valuation, Journal of Finance, forthcoming.

Dyck, A., and L. Zingales, 2003, Private benefits of control: an international comparison, Journal of Finance, forthcoming. 
Foerster, S., and G. A. Karolyi, 1999, The effects of market segmentation and investor recognition on asset prices: evidence from foreign stocks listing in the United States, Journal of Finance 54, 981-1013.

Francis, J., I Khurana, and R. Pereira, 2003, Global evidence on incentives for voluntary accounting disclosures and the effect on cost of capital, working paper, University of Missouri at Columbia.

Gill, A., 2001, Credit Lyonnais Securities Asia. Corporate Governance in Emerging Markets: Saints and Sinners, Who's got religion?, available at: http://www.worldbank.org/wbi/banking/finsecpolicy/domestic2003/readings.html.

Glaeser, E., S. Johnson and A. Shleifer, 2001, Coase versus the Coasians, Quarterly Journal of Economics 116, 853-899.

Henderson, B., N. Jegadeesh, and M. Weisbach, 2003, World markets for raising new capital, working paper, University of Illinois.

Hope, O.-K., 2003, Firm-level disclosures and the relative roles of culture and legal origin, Journal of International Financial Management and Accounting 14, 218-248.

John, K., and S. Kedia, 2003, Institutions, markets, and growth: a theory of comparative corporate governance, working paper, NYU.

John, K., and S. Kedia, 2004, Design of corporate governance: monitored debt, takeovers, and ownership structure, working paper, NYU.

Johnson, S., P. Boone, A. Breach, and E. Friedman, 2000, Corporate governance in the Asian financial crisis, Journal of Financial Economics 58, 141-186.

Palepu, K., T. Khanna, and J. Kogan, and, 2002, Globalization and similarities in corporate governance: a cross-country analysis, working paper, Harvard Business School.

Klapper, L., and I. Love, 2003, Corporate governance, investor protection and performance in emerging markets, Journal of Corporate Finance, forthcoming.

Krishnamurti, C., A. Sevic, and Z. Sevic, 2003, Legal environment, firm-level corporate governance, and expropriation of minority shareholders in Asia, working paper, Nanyang Technological University, Singapore.

La Porta, R., F. Lopez-de-Silanes, A. Shleifer, and R. Vishny, 1998, Law and finance, Journal of Political Economy 106, 1113-1155.

La Porta, R., F. Lopez-De-Silanes and A. Shleifer, 1999, Corporate ownership around the world, Journal of Finance 54, 471-517.

La Porta, R., F. Lopez-De-Silanes, A. Shleifer, and R. Vishny, 2002, Investor protection and corporate valuation, Journal of Finance 57, 1147-1170.

Leuz, C., and F. Olberholzer-Gee, 2003, Political relationships, global financing, and transparency, working paper, The Wharton School, University of Pennsylvania. 
Licht, A., 2003, Cross-listing and corporate governance: Bonding or avoiding? Chicago Journal of International Law, Vol. 4, Spring,

Lombardo, G. and M. Pagano, 2001, Law and equity markets: A simple model, in Corporate Governance Regimes: Convergence and Diversity, edited by Joe McCahery, Pieter Moerland, Theo Raaijmakers and Luc Renneboog, Oxford University Press, 2002, 343362.

Patel, S., A. Balic, and L. Bwakira. 2002, Measuring transparency and disclosure at firm-level in emerging markets, Standard and Poor's.

Perino, M., 2003, American corporate reform abroad: Sarbanes-Oxley and the foreign private issuer, European Business Organization Law Review, forthcoming.

Pistor, K., M. Raiser, and S. Gelfer, 2000, Law and finance in transition economies, The economics of transition 8, 325-368.

Rajan, R., and L. Zingales, 1998, Financial dependence and growth, American Economic Review $88,559-586$.

Reese, W., and M. Weisbach, 2002, Protection of minority shareholder interests, cross-listings in the United States, and subsequent equity offerings, Journal of Financial Economics 66, 65-104.

Rogers, W., 1993, Regression standard errors in clustered samples. Stata Technical Bulletin 13, 19-23.

Siegel, J., 2004, Can foreign firms bond themselves effectively by renting U.S. securities laws?, Journal of Financial Economics, forthcoming.

Shleifer, A., and R. Vishny, 1997. A survey of corporate governance, Journal of Finance 1997, $52,737-783$.

Shleifer, A., and D. Wolfenzon, 2002, Investor protection and equity markets, Journal of Financial Economics 66, 3-27.

Smarzynska, B., and S. Wei, 2002, Corruption and cross-border investment: firm-level evidence, working paper, NBER.

Stulz, R., 1999, Globalization, corporate finance, and the cost of capital, Journal of Applied Corporate Finance 12, 1999, 8-25.

White, H., 1980 A heteroskedasticity-consistent covariance matrix estimator and a direct test for heteroskedasticity, Econometrica 48, 817-838.

Williams, R., 2000, A note on robust variance estimation for cluster-correlated data, Biometrics $56,645646$.

Zimmerman, J., 1983, Taxes and firm size, Journal of Accounting and Economics 5, 119-149. 


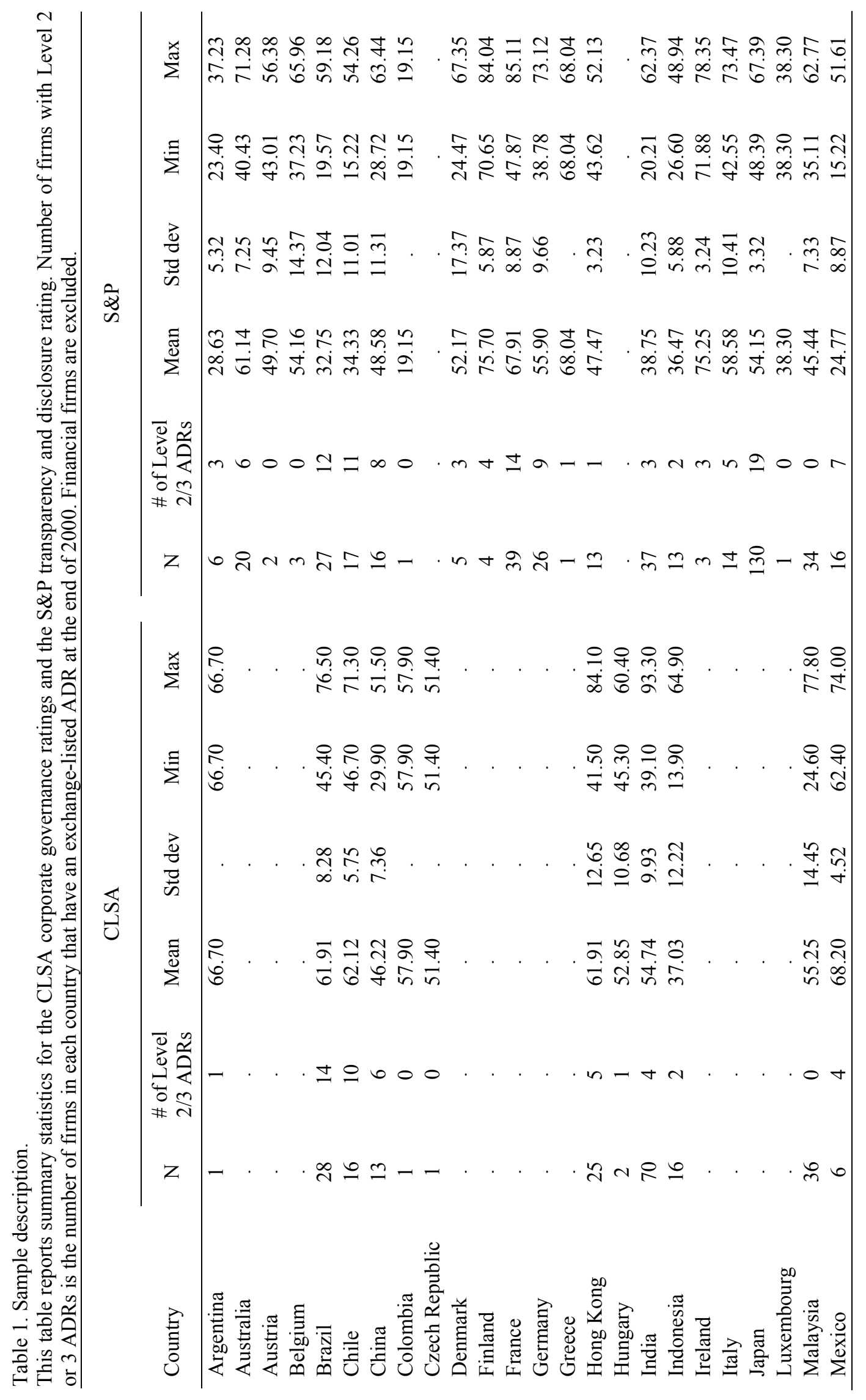




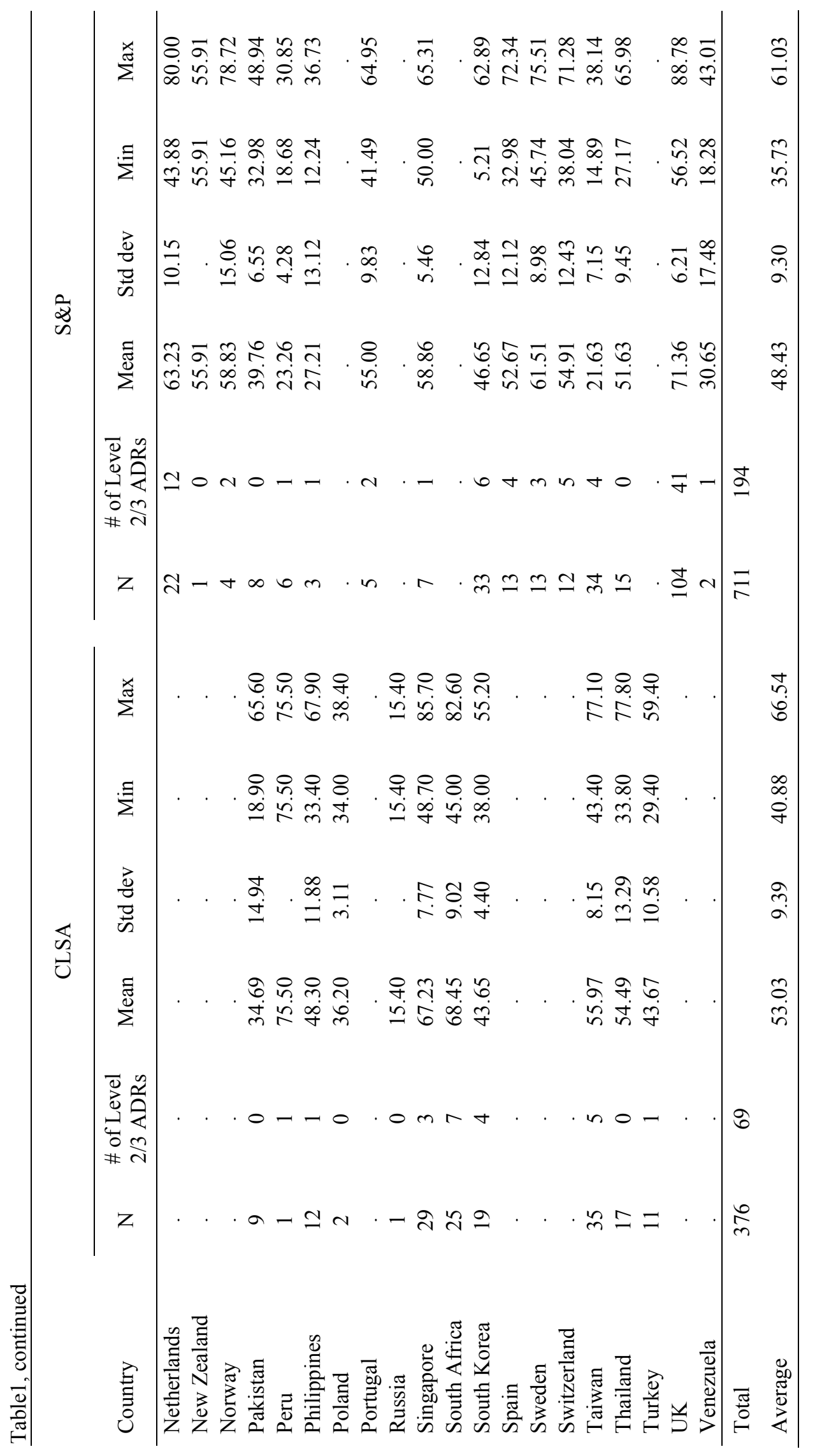


Table 2. The importance of country vs. firm characteristics.

The dependent variable in each regression is either the CLSA corporate governance rating (Panel a) or the S\&P transparency and disclosure rating (Panel b). Firm-level data is from Worldscope. Sales growth is inflation adjusted two-year sales growth from 1998 - 2000 (winsorized at 1\% and $99 \%$ tails). Ownership, Total assets (US\$ millions) and Cash/Assets are for 2000. Data for Dependence on external finance, computed as capital expenditures minus cash flow from operations divided by capital expenditures, is from Computstat from 1995-2000. Legal is Anti-director * Rule of law, which are from LLSV (1998). Log of GNP per capita (U\$) is for 2000 and is from the World Bank WDI Database. Stock market capitalization to GDP is from Beck, Demirguc-Kunt, and Levine (2001). The standard errors are computed assuming observations are independent across countries, but not within countries. t-statistics are in parentheses. The F-statistic tests the hypothesis that the firm-level variables (country) are jointly equal to zero. *, **, and *** indicate statistical significance at the $10 \%, 5 \%$, and $1 \%$ levels, respectively.

Panel a. CLSA governance rating.

\begin{tabular}{|c|c|c|c|c|c|}
\hline & \\
\hline & (1) & (2) & (3) & (4) & (5) \\
\hline \multirow[t]{2}{*}{ Constant } & 54.57 & 35.67 & 37.73 & 44.19 & 48.24 \\
\hline & $(12.82)^{* * *}$ & $(3.67)^{* * *}$ & $(4.55)^{* * *}$ & $(11.83)^{* * *}$ & $(8.62)^{* * *}$ \\
\hline \multirow[t]{2}{*}{ Sales growth } & 5.44 & & 4.92 & & 1.86 \\
\hline & $(2.74)^{* *}$ & & $(2.16)^{* *}$ & & $(1.13)$ \\
\hline \multirow[t]{2}{*}{ Dependence on external finance } & 1.49 & & 1.56 & & 0.07 \\
\hline & $(1.51)$ & & $(1.57)$ & & $(0.09)$ \\
\hline \multirow[t]{2}{*}{ Ownership } & -0.76 & & 1.04 & & 2.40 \\
\hline & $-(0.15)$ & & $(0.24)$ & & $(0.69)$ \\
\hline \multirow[t]{2}{*}{ Log(Assets) } & -0.23 & & -0.99 & & -1.08 \\
\hline & $-(0.30)$ & & $-(1.40)$ & & $-(1.43)$ \\
\hline \multirow[t]{2}{*}{ Cash/Assets } & 16.29 & & 8.13 & & 11.51 \\
\hline & $(3.30)^{* * *}$ & & $(1.72)^{*}$ & & $(2.15)^{* *}$ \\
\hline \multirow[t]{2}{*}{ Legal } & & 0.51 & 0.47 & & \\
\hline & & $(2.34)^{* *}$ & $(2.26)^{* *}$ & & \\
\hline \multirow[t]{2}{*}{ Log GNP / capita } & & 1.25 & 1.65 & & \\
\hline & & $(0.93)$ & $(1.18)$ & & \\
\hline \multirow[t]{2}{*}{ Stock market capitalization / GDP } & & -1.11 & -1.21 & & \\
\hline & & $-(0.40)$ & $-(0.49)$ & & \\
\hline Country dummies & no & no & no & yes & yes \\
\hline F-statistic: firm-level variables & $9.06^{* * *}$ & & $6.25^{* * *}$ & & $4.00^{* * *}$ \\
\hline F-statistic: country-level variables & & $5.86^{* * *}$ & $6.66^{* * *}$ & & \\
\hline Adjusted $\mathrm{R}^{2}$ & 0.0424 & 0.1474 & 0.1818 & 0.3860 & 0.4074 \\
\hline \# of observations & 309 & 309 & 309 & 309 & 309 \\
\hline
\end{tabular}


Table 2, continued.

\begin{tabular}{|c|c|c|c|c|c|}
\hline & \multicolumn{5}{|c|}{ Panel b. S\&P transparency and disclosure rating. } \\
\hline & (1) & (2) & (3) & (4) & $(5)$ \\
\hline \multirow[t]{2}{*}{ Constant } & 23.71 & 5.56 & 7.52 & 30.64 & 16.37 \\
\hline & $(2.33)^{* *}$ & $(0.54)$ & $(0.77)$ & $(5.18)^{* * *}$ & $(3.88)^{* * *}$ \\
\hline \multirow[t]{2}{*}{ Sales growth } & -4.20 & & -2.68 & & 0.29 \\
\hline & $-(0.67)$ & & $-(0.44)$ & & $(0.19)$ \\
\hline \multirow[t]{2}{*}{ Dependence on external finance } & 1.50 & & 1.97 & & 1.39 \\
\hline & $(2.09)^{* *}$ & & $(2.98)^{* * *}$ & & $(2.41)^{* *}$ \\
\hline \multirow[t]{2}{*}{ Ownership } & -16.69 & & -7.09 & & 1.20 \\
\hline & $-(1.68)$ & & $-(1.09)$ & & $(0.49)$ \\
\hline \multirow[t]{2}{*}{ Log(Assets) } & 4.03 & & 2.75 & & 1.78 \\
\hline & $(4.87)^{* * *}$ & & $(2.86)^{* * *}$ & & $(3.58)^{* * *}$ \\
\hline \multirow[t]{2}{*}{ Cash/Assets } & 10.53 & & 3.70 & & 4.13 \\
\hline & $(2.71)^{* *}$ & & $(1.06)$ & & $(1.43)$ \\
\hline \multirow[t]{2}{*}{ Legal } & & 0.23 & 0.24 & & \\
\hline & & $(1.22)$ & $(1.42)$ & & \\
\hline \multirow[t]{2}{*}{ Log GNP / capita } & & 3.80 & 1.35 & & \\
\hline & & $(2.76)^{* * *}$ & $(1.00)$ & & \\
\hline \multirow[t]{2}{*}{ Stock market capitalization / GDP } & & 4.97 & 5.37 & & \\
\hline & & $(1.24)$ & $(1.41)$ & & \\
\hline Country dummies & no & no & no & yes & yes \\
\hline F-statistic: firm-level variables & $8.99^{* * *}$ & & $5.77^{* * *}$ & & $5.52^{* * *}$ \\
\hline F-statistic: country-level variables & & $9.05^{* * *}$ & $4.60^{* * *}$ & & \\
\hline Adjusted $\mathrm{R}^{2}$ & 0.2249 & 0.2996 & 0.3515 & 0.7338 & 0.7515 \\
\hline \# of observations & 667 & 667 & 667 & 667 & 667 \\
\hline
\end{tabular}




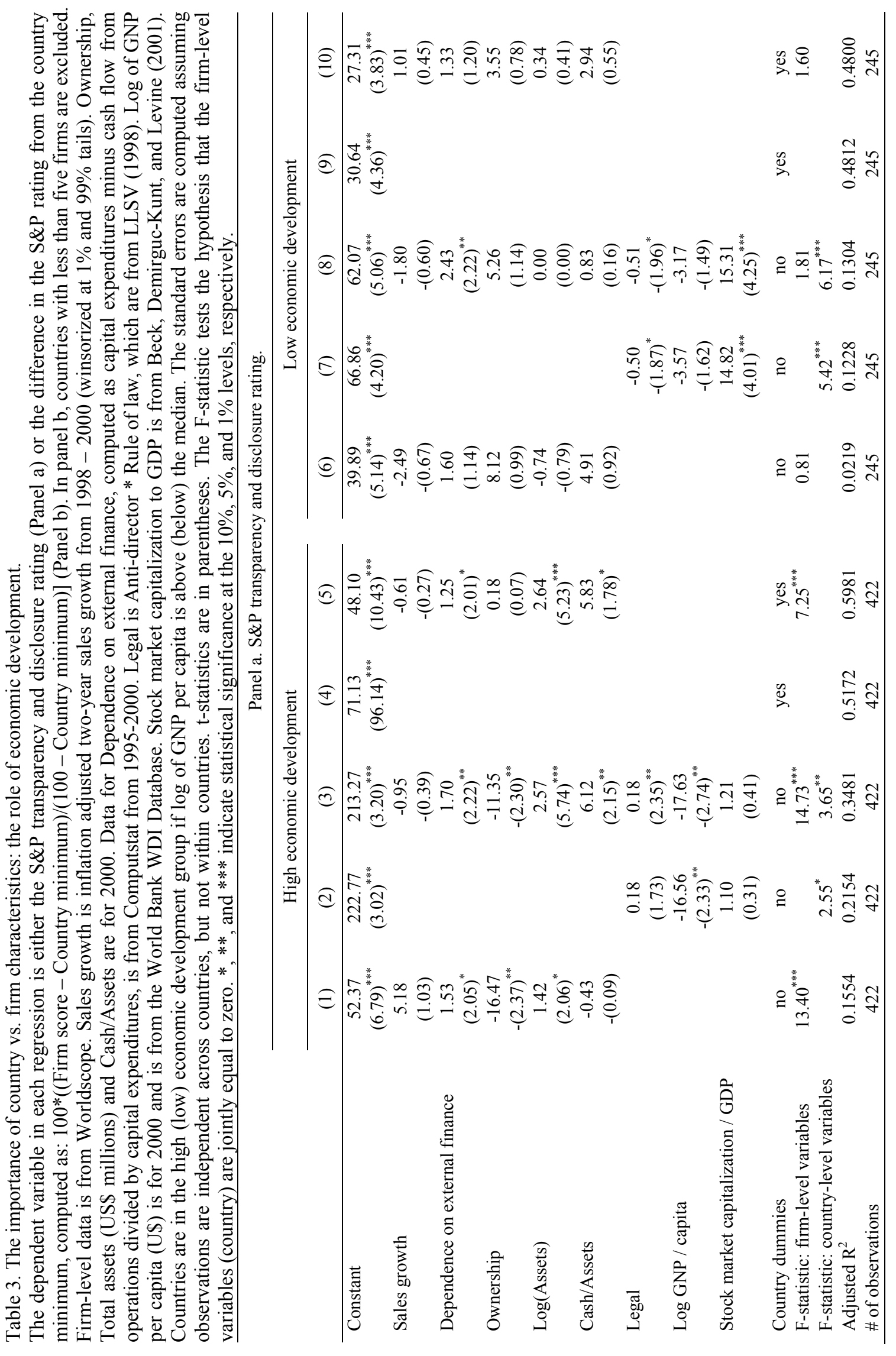




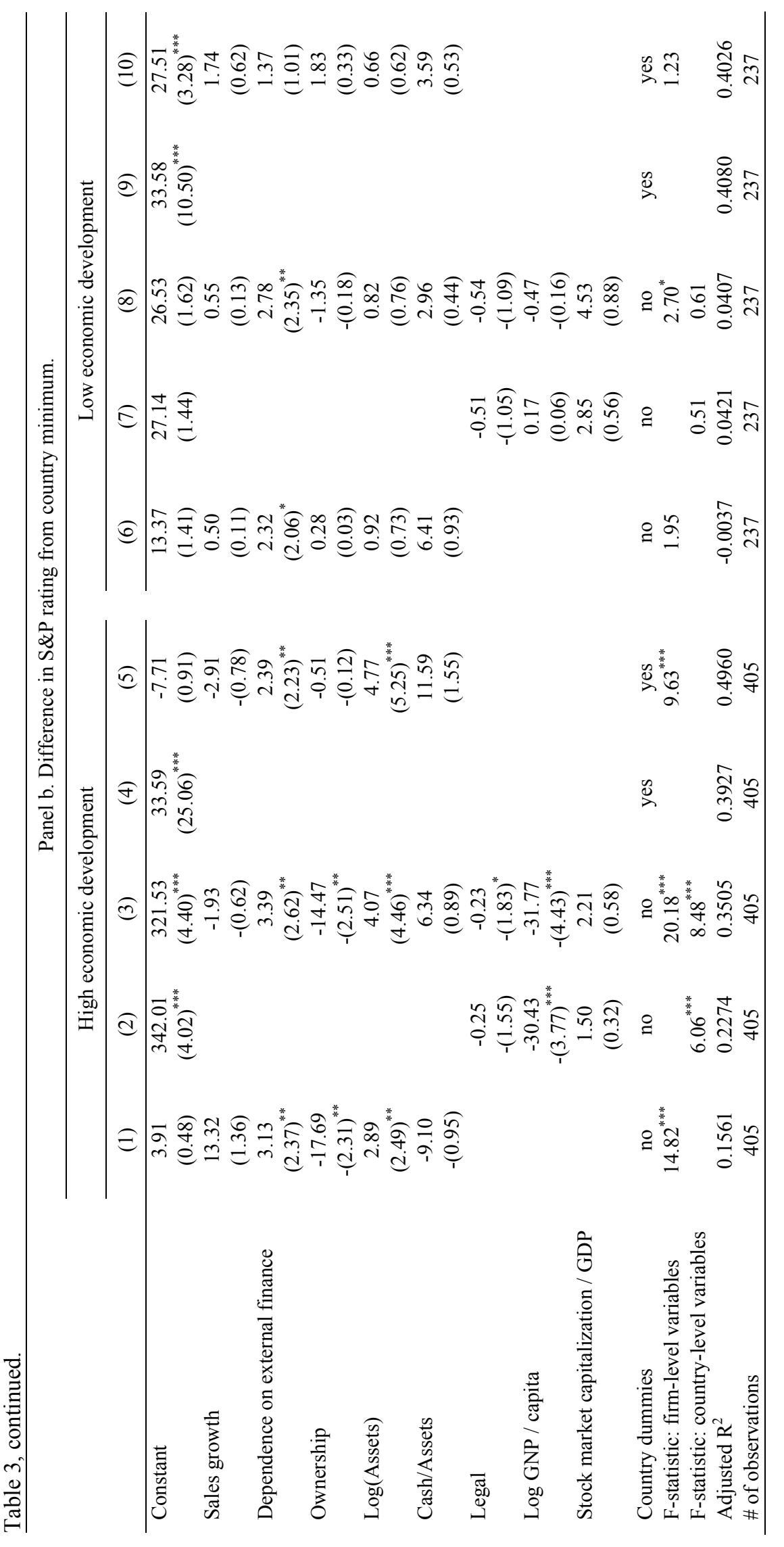




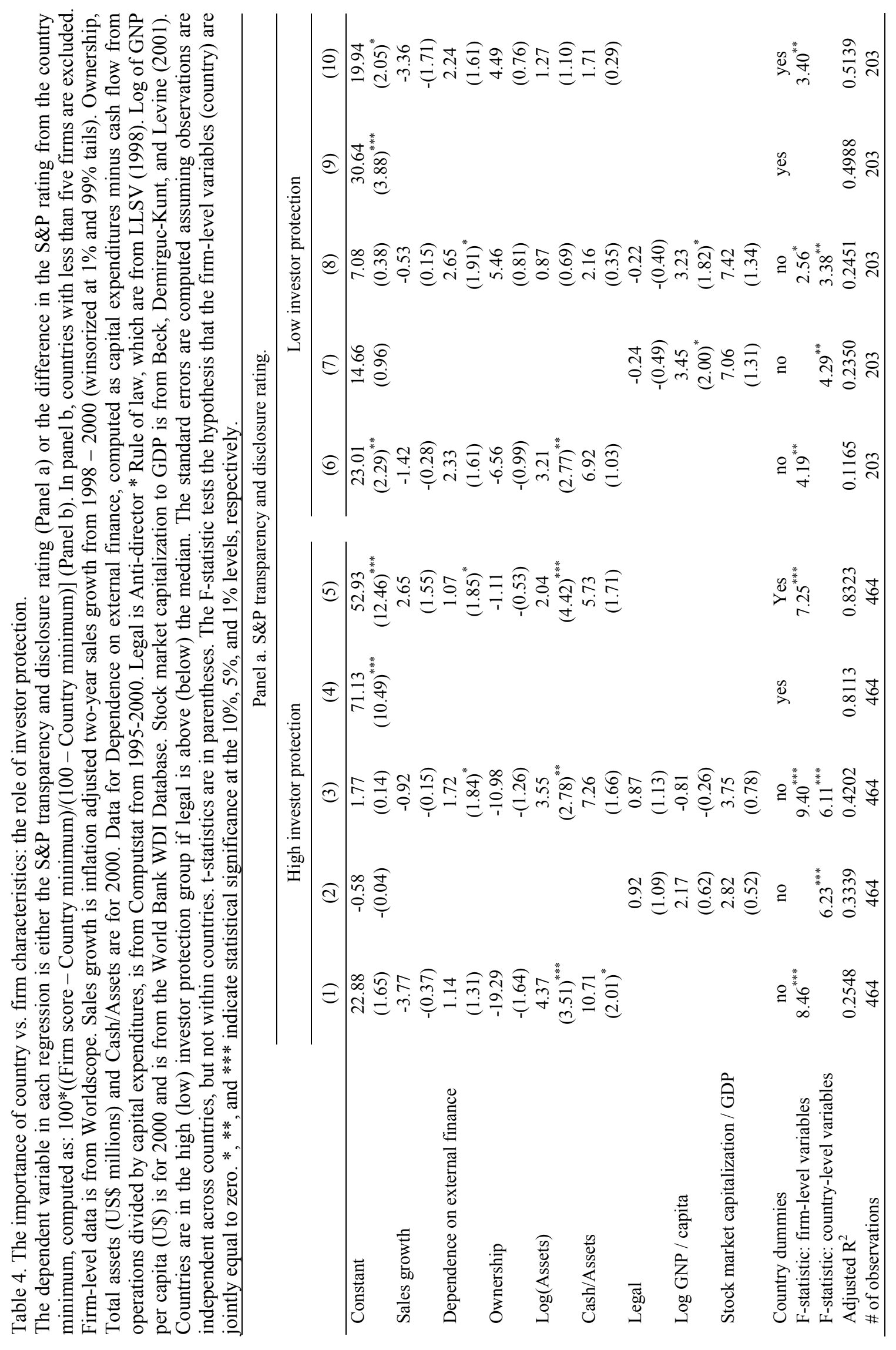




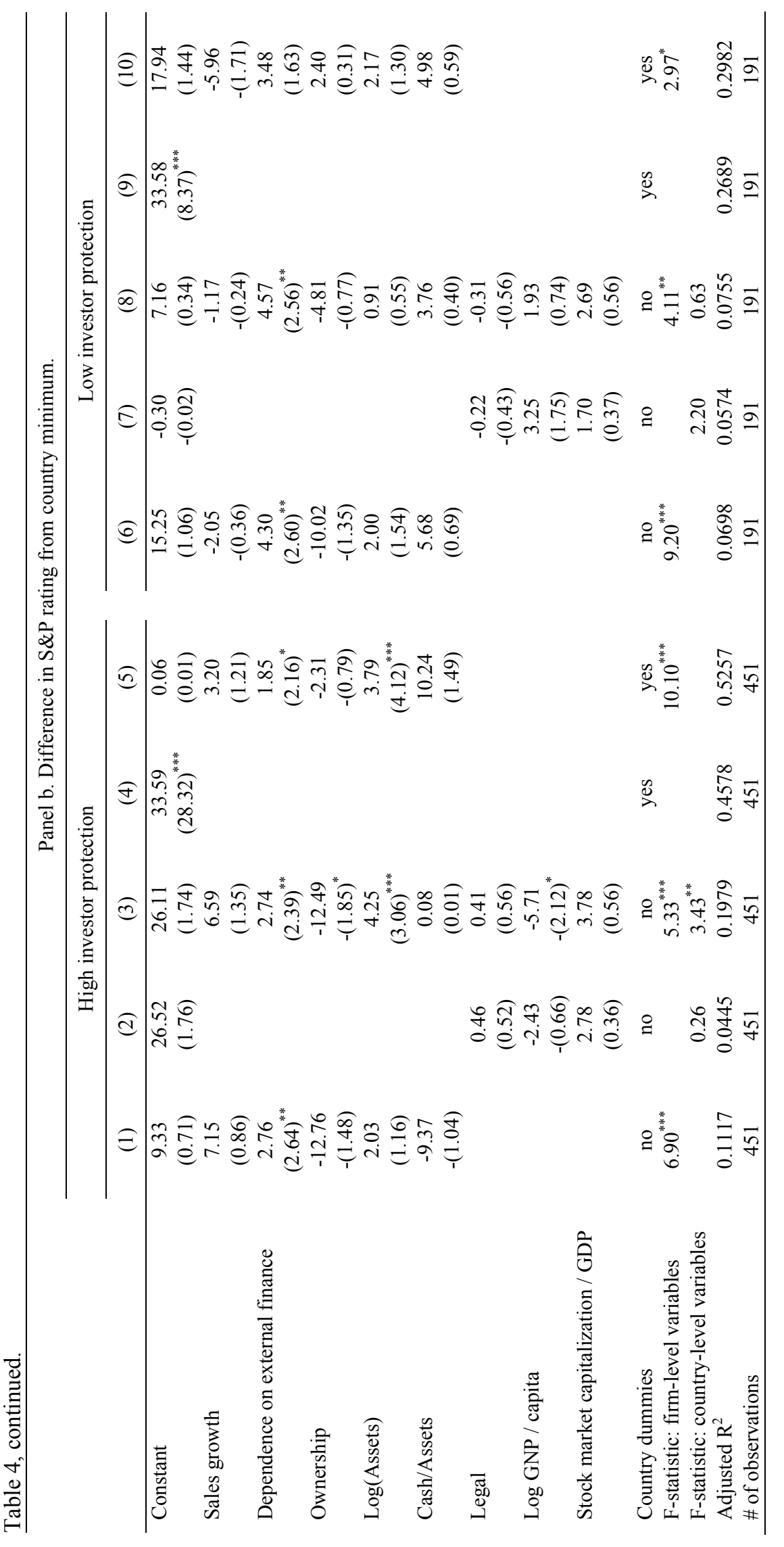




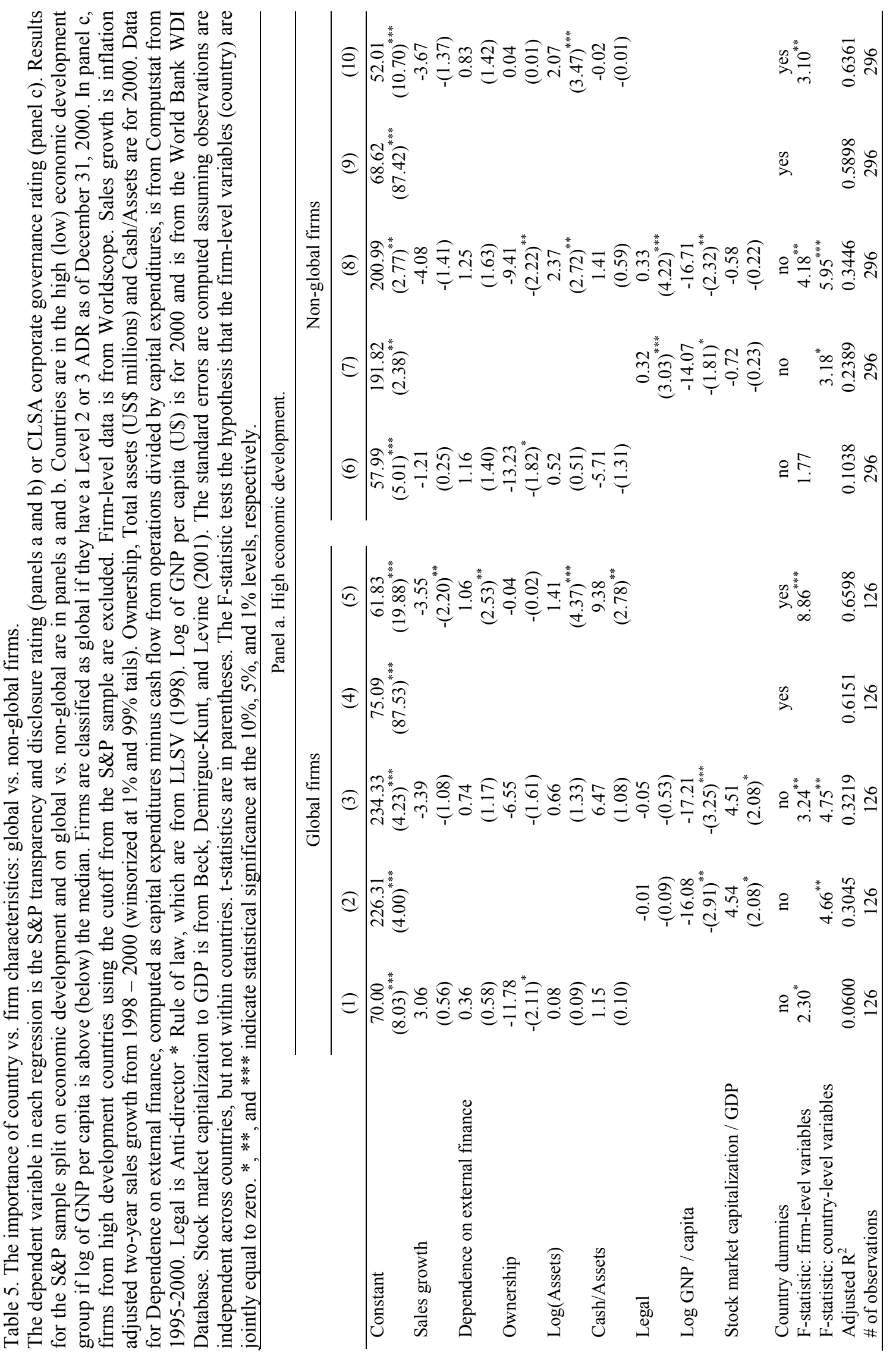




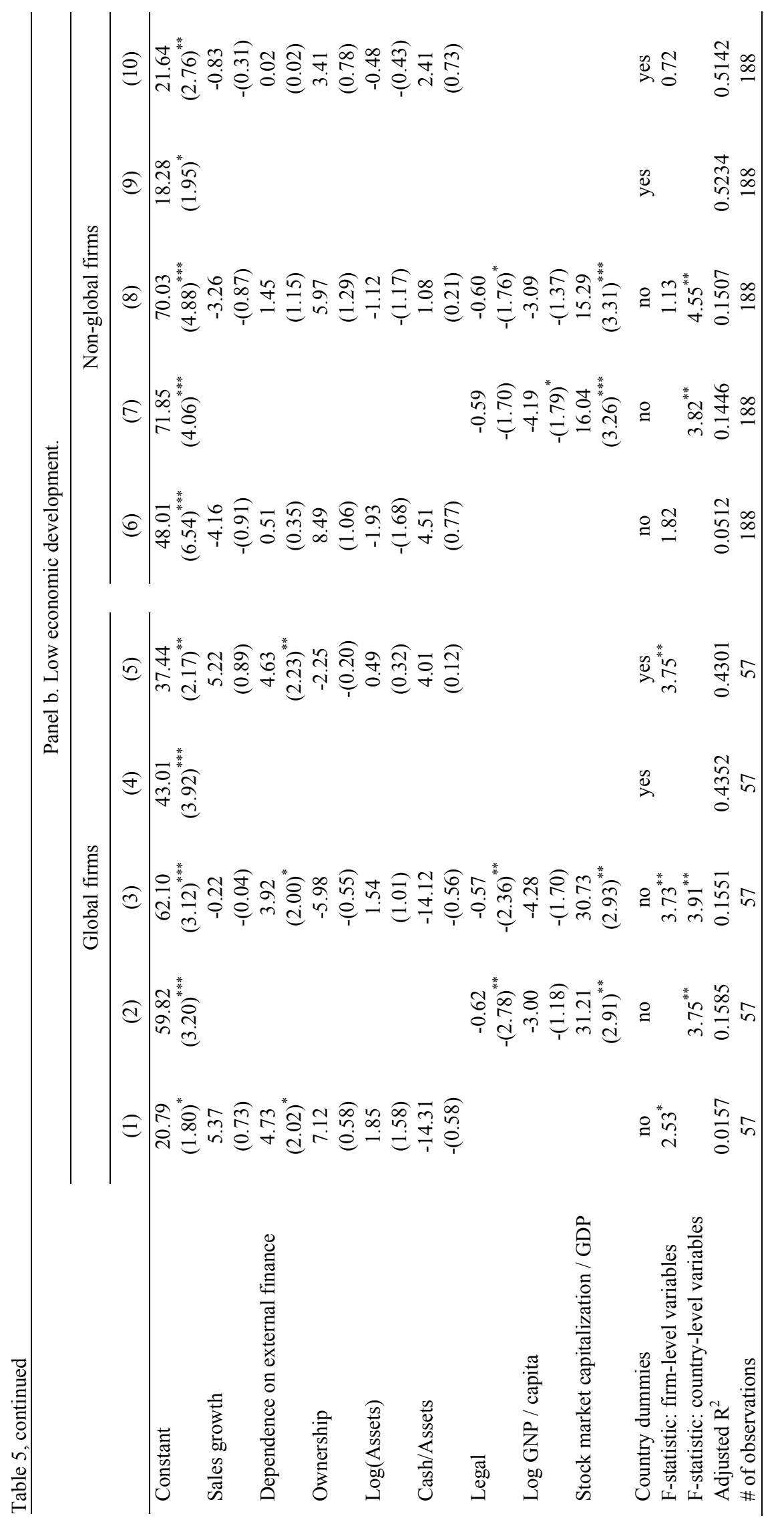




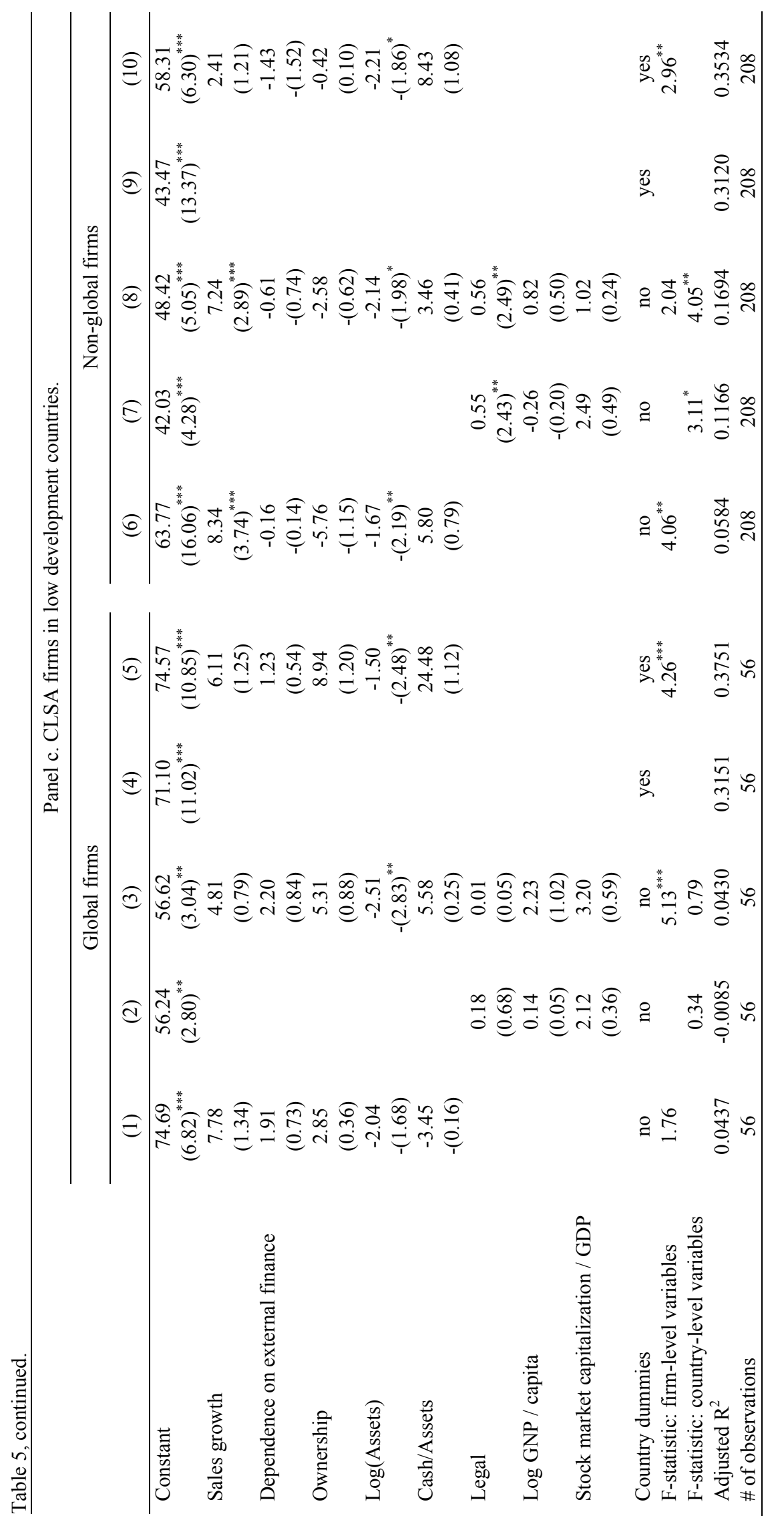




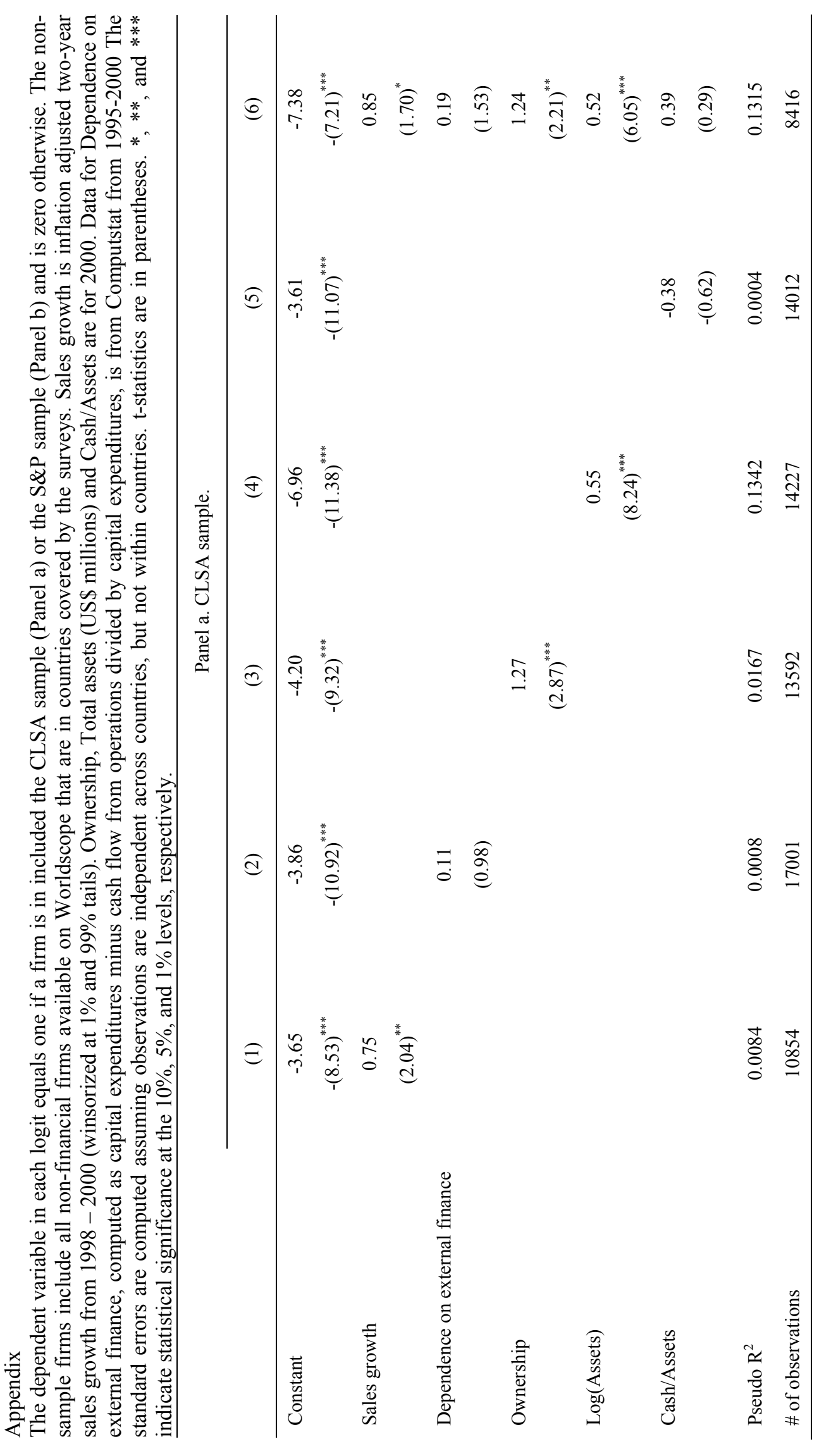




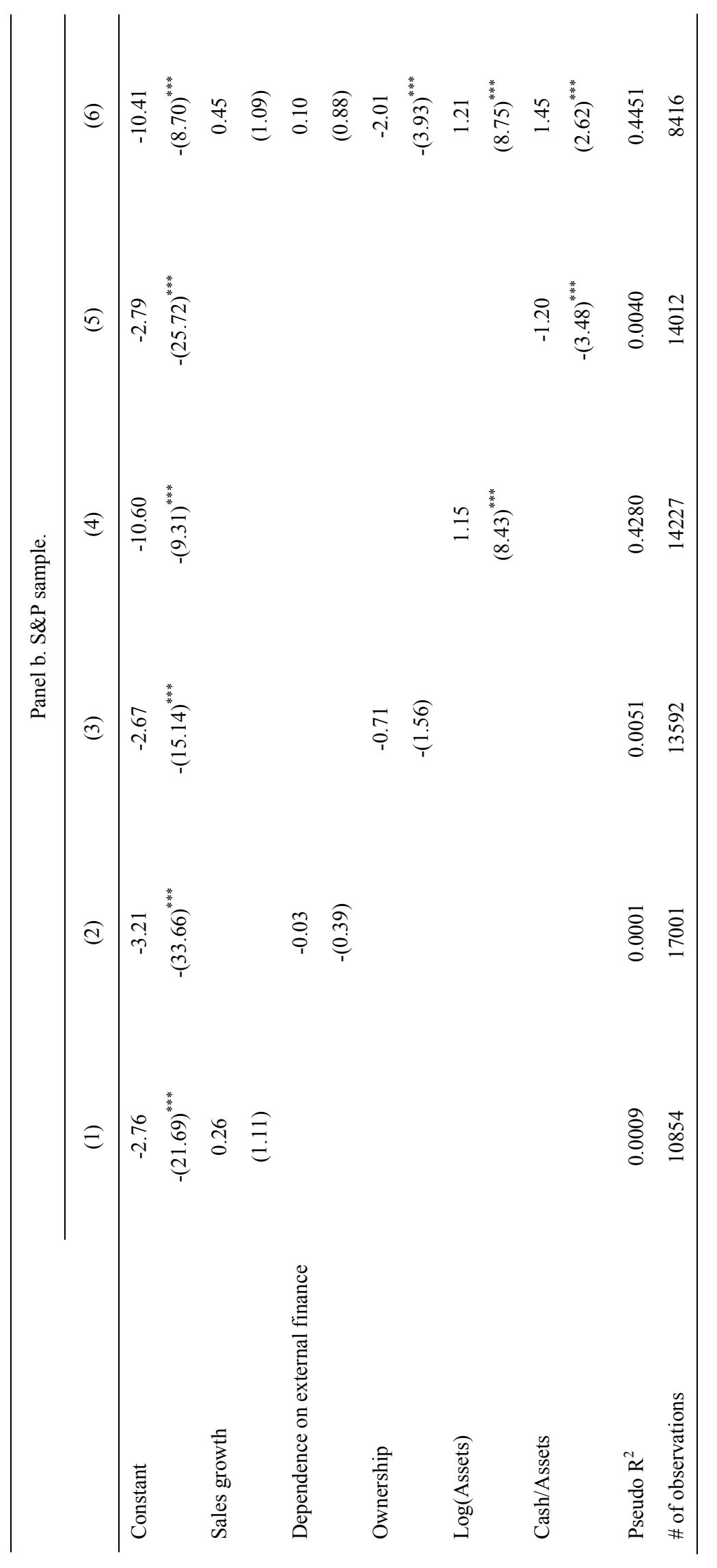

ก 